\title{
Equal Opportunity Rule vs. Market Rule in Transfer of Control: How Can Private Benefits Help to Provide an Answer?
}

\author{
Hubert de La Bruslerie \\ Professor of Finance \\ University Paris-Dauphine*
}

\begin{abstract}
:
Having been introduced in the European Union and in many other countries, the equal opportunity rule is seen as protecting investors in the event of a transfer of control. This rule should be analyzed in a context of appropriation of private benefits between the new controlling shareholders and the outside investors. Both parties need to design a new implicit contract to share the firm's ownership. Using a signaling model, we show that the new controlling shareholder issues signals to outside shareholders to deliver private information on a firm's future economic return and her private rate of appropriation. The ownership stake of the controlling shareholder and the premium embedded in the acquisition price are key parameters. In a controlling ownership system, the equal opportunity rule modifies the relative behavior of controlling and outside shareholders. The quality of information deteriorates but the discipline on appropriation may become stronger.
\end{abstract}

Keyword: Equal opportunity rule, transfer of control, takeover, controlling shareholder, investors protection, private benefits

JEL: G3 / G34 / G38 / K2

\footnotetext{
* DRM-Finance UMR 7088, Place du Mal de Lattre 75116 Paris-France, phone: (33) 1440544 05, mail : hlb@dauphine.fr

I thank discussants at the 7th annual CIG Conference in Bordeaux, the 2009 Brest AFFI Conference, the 2009 Milano EFMA meeting and the 2010 Wiesbaden GLEA meeting. P. Six should be particularly mentioned for his help in a first version of the paper. The financial support of the Fédération Bancaire Française Chair in Corporate Finance is greatly acknowledged.
} 


\section{Introduction}

Transfers of control aim at disciplining a firm's management and improving its performance. They are a key mechanism in the optimal use of capital and, from a welfare point of view, the regulation of transfer of control is of upmost importance. A recent paper by Enriques et al. (2013) contests this idea and states that the regulation design of transfer of control should be set at firm levels and that designing regulation at a country level is not optimal. Firms are better positioned to decide which rule in a menu of rules is better suited to develop a specific category of contract named transfer of control. They state that takeover regulations should neither hamper nor promote takeovers, but instead allow individual companies to decide the contestability of their control. This idea is new and reopens the controversy of the optimal regulation of takeovers.

The traditional controversy opposes two legal regimes for transfer of control. The first one is the Market Rule, which is opposed to the Equal Opportunity Rule (Bechuk, 1994). The Market Rule (also known as the "Street" rule) confers maximum freedom on a company's incumbent controller by enabling sale shares (hence control over the target company) to any acquirer offering an acceptable price. This applies to most private sale-of-control transactions in the USA. The Equal Opportunity Rule (EOR, also termed Mandatory Bid Rule) has its origins in the UK and now applies throughout the EU and in many other countries. Under a mandatory bid, an acquirer of a controlling stake in a listed company has to offer the remaining shareholders a buy-out of their minority stakes at a price equal to the payment received by the incumbent controller. A definition of a controlling stake is needed to trigger the EOR. Most countries chose to apply a threshold of $30 \%$ of the voting rights.

This theoretical controversy seemed to have been overlooked for a long period as the institutional environment is settled by government regulations. However, this is not because institutional regulations have been enforced here or there that the question has no more interest. Historical considerations, ideology and pressures by group may explain why the Market Rule (MR) prevails in the US law. It is nevertheless with some exceptions: the states of Maine and Pennsylvania have Mandatory Bid Rules (Grant et al., 2009). The choices between MR and EOR are not permanent and irrevocable, as the European Union illustrated in 2005. The EOR 
was then enforced at the EU level and many European countries abandoned the Market Rule system. A geographical comparison shows that the EOR principle is now dominant in many countries in the world as in Australia, Hong Kong, Russia, Singapore, South Africa, Switzerland, Japan and, to some extent, in Canada (at least if the bidder pays a premium in excess of $15 \%$ over the market price).

The theoretical analysis has not definitely ruled over the optimal regime to develop transfer of control. Historically a large strand of the literature is in favor of the Market Rule (Bebchuk, 1994). The controversy between EOR and MR experiences a revival driven mostly by legal analysis and empirical studies. In recent contributions, Papadopoulos (2007, 2013), Sepe (2010) and Enriques (2012) argue against EOR, emphasizing its cost and deficiencies, mainly in the EU context. Their analysis is mostly grounded on legal arguments and they remark that EOR did not lead to the integration of the market of transfer of control in Europe. On the pros side, McCahery and Vermeulen (2010) support the existing EOR rules in the EU. Schuster $(2010,2013)$ mentions that the costs associated with mandatory bids are not so high in comparison to its advantages. Enriques et al. (2013) propose that EOR should be recognized as a part of an "unbiased" takeover law to set up. Carvalhal and Subrahmanvam (2007) empirically analyzed the presence and removal of mandatory bid rule in Brazil where opt out possibilities exist at the firm level. They identify an influence of the rule on the premium size.

This question develops in a framework where private benefits exist as synergies are expected in a takeover. The capture or the sharing of these private benefits is the basic problem that exists irrespective of the level of protection awarded by the legal system to investors. The ability to extract private benefits is not only a function of the legal system. Shareholding concentration is identified in most countries, even in common law countries such as the USA (Holderness, 2009). Dyck and Zingales (2004) demonstrated the worldwide existence of private benefits, even in developed capital markets and protective legal environment. They show that private benefits amount to $2.7 \%$ of the equity capital of US firms. Albuquerque and Schroth (2010) estimate that private benefits represent 3-4\% of the target firm's equity of a sample of US acquisitions. Unfortunately these two studies do not address the question of the possible effect of the EOR rule.

Taking into account the existence and the importance of private benefits is crucial in transfers of control. In the same legal environment, the pyramidal structure of firms may 
explain different terms in acquisitions. Atanasov et al (2010) considered a US sample of acquisitions of a subsidiary by a parent company. The authors show that subsidiaries bought by parents owning a minority stake are valued at a median $23 \%$ discount compared to peers. When considering majority-owned subsidiaries, they see no abnormal performance or valuation with peers. Even in a Market Rule system, appropriation exists and seems to be linked with the stake of controlling ownership. The issue of blockholder opportunism in the United States is however questioned by analyses showing that non-U.S. firms will choose to cross-list on U.S. stock exchange to bolster investor protection (Doidge et al., 2004).

Private benefits are by-products of this situation of control and appear either in the form of a pre-existing rent of control (Bebchuk, 1989), or of expected synergies by the acquirer. Even if private benefits are lower in countries where the investor's protection is good, they still exist particularly in private firms (La Porta et al., 1998). In that vein, a macro comparison of country corporate governance rules is often used to explain the difference in cross-border acquisitions (for instance, Bris and Cabolis, 2008; Kim and Lu, 2013). Nevertheless, at a macro country level the degree of investor protection cannot be seen as totally exogenous (Pagano and Volpin, 2005)

Even within the USA, differences exist between the states laws and the levels of antitakeover protection. Boone and Mulherin (2007) identify nine states among 50 where the antitakeover environment is strong. Surprisingly it seems that antitakeover states will make target firms more prone to choose negotiation. Indirectly it has some wealth effect where a negotiated process creates less value than a multi-bidders auction. These results are not crossed with the possibility of private benefits. The issue of the effect of takeover regulation on the process conditioning the transfer of control is still pending even in a single country framework.

However, the analysis of the takeover decision should be set at the firm's level. Private benefits are micro decisions which are set conditionally with regard to the legal constraints. For instance, these legal rules can be sketched using the probability of being sued and convicted, a monetary sanction and the cost of a takeover. At et al. (2004) show that in such a legal framework the controlling bidder can be driven to optimally acquire more than $50 \%$ of the shares. If they take into account the fine, they ignore the legal constraint introduced by the MR or the EOR on the takeover terms. 
How does the transfer of control develop in a situation where private benefits exists? The question is not only geographical and /or empirical with a comparison of M\&A activity between countries where different rules apply. Which rule, EOR or MR, helps or hurts the transfer of control the least, is a too simple question. The optimality of the regulation is often addressed in a scheme where the rule is exogenous so behaviors will integrate the constraints and costs imposed by the rules. We have to consider the existence of a situation of control of the firm by an incumbent controlling shareholder who is willing to sell it to an acquirer. The private benefits are not mechanically conditioned by the legal environment, so we will follow the idea that the anticipated future private benefits are endogenously determined in the takeover process.

Within an equal opportunity rule framework, when the takeover is initiated the outside shareholders have to choose between keeping their shares and selling them at an acquisition price that is always above the market price. Why, in an apparently irrational way, do outside shareholders, who benefit from a guaranteed price, not systematically sell their shares? Although tax reasons may explain it, many investors will refuse to accept an open unconditional bid. This puzzling question has not been extensively analyzed in the literature.

The basic question raised by the EOR is how the two preoccupations, optimality of transfer of control and cost/advantage of investors' protection, combine. Whatever the procedure or the form of transfer (public tender offer or private block trade), a new controlling shareholder substitutes for an old one. Albuquerque and Schroth (2010) show that in the USA the private benefits represent a similar part of the equity for the selling controller and the buying controller. As for the third party, outside investors face a new economic story and the firm in which they had previously invested becomes another economic project. Empirical analyses have mainly focused on ex post realized transactions. What is relevant is to analyze the influence of regulation ex ante on those transfers of control that were not ex post realized. Losses in optimality can be identified and can be put into balance with the actual protection of outside investors and the future profit they would have made under a simple Market Rule. The complexity of reassessing the history under different institutional environment explains the paucity of empirical results in the literature. Behavioral and experimental studies may be a promising field, yet not explored. Therefore, we need to compare how the setting of the terms 
of a transfer of control are influenced by the existence or an EOR. Boone and Mulherein (2007) insist on the importance of the prior private phase in the takeover process. They show that negotiation develops and that competition is stronger during this first phase than in the ensuing public phase of the bid. Considering a sample of 400 US takeovers, one-half of the target firms are auctioned by multiple bidders in the takeover process and the other half negotiates with only a single bidder. The choice between both channels is not harmful to the target's shareholders. The ex-post wealth effects are comparable. As consequence there is a need to focus on the private phase in the takeover process. This negotiation step is of course dominant in block transactions. We analyze the issue of EOR in the framework of a quasi-contractual process. We contribute to the literature, as Boone and Mulherin (2007) do not refer explicitly to the mandatory bid provision.

The relevant method is to use a contractual model as the valuation of the firm develops in a joint economic valuation framework between the new ruling shareholders and the outside investors. The problem is made complex in EOR because outside investors are not passive and will act to optimize the percentage of shares they sell back to the initiator at the acquisition price. We analyze this as an implicit contract mixing agency problems of future private benefits and signaling problems of delivering private information. Equilibrium is established through the two key parameters of an offer: the size of the block of control and the acquisition price.

In the paper, we show that, in an EOR context, both parties design the characteristics of an implicit contract in order to share the firm's ownership. Through a signaling process, outside investors will integrate an expected level of future private benefits into their valuation schedule. We show that the new controlling shareholder delivers private information to the outside shareholders on two key variables: the firm's future economic return and the rate of private appropriation. As in the Leland and Pyle (1977)'s framework, ownership is a good signal: the higher the share of capital held by the controlling shareholder, the better the prospects of future economic return as perceived by outsiders. Another signaling effect results from the premium embedded in the acquisition price: the future profitability of the target under the buyer's ownership is increasing in the acquisition price. The buyer's private appropriation of future benefits also appears to the investors to be decreasing in the share the buyer acquires. In an EOR context, we highlight that the buyer takes into account the inferences the outside shareholders draw from his choices. The setting of EOR rule enforces a constraint because the buyer is no longer completely free to set the share of the capital he wants to purchase: the investors can force that share up by tendering their stocks to the buyer. 
A major result is that the final stake that an acquirer obtains in a takeover subject to the EOR is endogenous to the minority shareholders' choice of how many of their shares to sell. How many shares minority shareholders sell, however, depends on the offer the acquirer makes and on the information that the shareholders infer from this offer. Through this channel, the EOR affects the acquirer's optimal offer. The equilibrium offer (and the minority shareholders' response) under the EOR is then compared to the equilibrium obtained in the absence of an EOR. Compared to the existing literature we demonstrate that under EOR outside investors influence the transfer of private benefits accompanying a transfer of control.

The setting of an EOR rule induces two specific consequences. Firstly, it initiates a selflimitation mechanism in future expropriation. Since the rate of expropriation is decreasing in the share the buyer acquires, he is encouraged to take a larger stake. The EOR exaggerates this process by giving the investors an exit option at the purchase price. The buyer can be forced to increase his stake involuntarily. The buyer's best response, since he does not want to buy the entire firm, is to reduce his rate of benefits appropriation. Secondly, in an EOR context, the bid price and the purchased share of the target company as signals are lower quality signals and convey less information to the market: the buyer's ability to signal is reduced by the exogenous constraint induced by the EOR. Moreover, we also explain why the exit option is only partially used by rational outside investors in an EOR system.

The empirical implications of our findings can follow four directions. Methodologically, the terms of the takeover will differ according to the capital concentration and the importance of private benefits. We show that the relevant analysis should focus jointly on the two key variables setting the transfer of control: the size of the controlling block and the acquisition premium. An empirical analysis has been proposed by Albuquerque and Schroth (2010) in a Market Rule context. A similar study could be done in an EOR environment. Secondly, the EOR may explain why some announced takeover failed due to the non-convergence of the contract process. The probability to agree to transfer control ceteris paribus is influenced by the EOR. An empirical test on envisaged but non-realized takeovers may be developed. Moreover, the importance of information delivery in the process of control is emphasized as it may help the agreement. The reduction of asymmetry of information should empirically be different in EOR or MR settings. This leads to a testable hypothesis. Lastly, a test comparing ex ante and ex 
post private benefits can be designed to check if the EOR has a disciplinary effect or not on private appropriation.

The remainder of the paper is divided into five parts. A review of the literature is presented in the second section. Section 3 presents the framework of a model referring to information asymmetries, future private benefits and expected economic return. Section 4 and Section 5 develop the model respectively without and within an EOR context. Conclusions are drawn in the final section.

\section{Literature}

The possibility and conditions of transfers of control have been extensively analyzed in the academic literature. In a well-known paper, Grossman and Hart (1980) showed that tender offers should be rare because a perfectly informed seller will ask for a price at least equivalent to the future value of the firm under a new management. The only possibility of stimulating buyers is the appropriation of a rent leading to the offer of a lower public offer price. Hirshleifer and Titman (1988) analyzed the impact of previous shareholding by the buyer, or toehold. Just like Bagnoli and Lipman (1988), Bebchuk (1989) showed that, even without any private appropriation by the buyer, the buyer initiates a takeover bid if he is able to increase the value of the firm.

In a controlling shareholder system, the dominant agency conflict that develops is the one with outside investors. Private benefits are levied by the controlling shareholder (Shleifer and Vishny, 1986, or La Porta, et al., 1999). The problem is estimating private benefits that are concealed from outside investors and that often result from negative management decisions (not to do something rather than doing it). This leads Hofstetter (2006) to ask why not make private benefits an explicit part of the corporate contract. The private benefits should be considered as an agency variable in the controlling-outside investors' relationship. In a controlling ownership system, some efficient level of private benefits balancing monitoring costs may exist (Burkart et al., 2000). The existence of private benefits can make the financing constraints more binding because they limit the pledgeable cash flow (Burkart et al., 2012). The latter analyze the influence of legal investor protection on takeovers outcome. However, Burkart et al. (2012) consider protection as a global constraint on the acquirer. They do not consider the specificity 
of the equal opportunity rule for outside investors and develop a model within the so-called Market Rrule .

Many empirical studies have tried to estimate the value of private benefits in the acquisition price by separating the part that corresponds to private benefits. Barclay and Holderness (1989), in examining takeovers in the USA, pointed out that large blockholders gets abnormally large benefits. In a later empirical study, Barclay et Holderness (1991) analyzed 106 block acquisitions and they show that in most cases (90\%), a new controlling buyer replaced the incumbent dominant stockholder. Control is a persistent situation, so are private benefits; and the transfer of control is a transfer of private benefits. Albuquerque and Schroth(2010) evaluate the difference between the private benefits of the seller and the buyer. They are very similar with the same skewed distribution. In the USA, they amount to $3.2 \%$ to $3.7 \%$ of the seller's equity and to 3.3 to $4.4 \%$ of the buyer's. These private benefits are significantly positive, contrary to the Dyck and Zingales' (2004) estimate of $2.7 \%$, which was insignificant.

In a majority block transaction, European regulation imposes a mandatory bid takeover aimed at minority shareholders. Schatt and Roy (2004) showed that the average stake of capital sold by outside investors in that framework represented an average stake of $25.7 \%$ of capital. In the end, the initiator obtained an average $90.8 \%$ of capital of the target firms. It should be outlined that the price guarantee mechanism attracted only three-quarters of outside shareholders, who will only partially use their exit opportunity. La Bruslerie and Deffains (2004) developed a contingent claim analysis of the equal treatment right given to outside shareholders and showed that only between half and three-quarters of the outside investors will exercise their "in-the-money" exit option.

The EOR rule has particular importance in the European context where a firm's ownership is concentrated (Berglof and Burkart, 2003; Goergen et al., 2005). Beside the mechanisms used for it, the transfer of control should refer to concentrated/diluted ownership systems (Burkart et al., 2000). The presence of a controlling shareholder is associated with potential opportunistic behavior towards minority or outside shareholders. These outside shareholders suffer the expropriation of private benefits from controlling shareholders. Although a large number of standard company law techniques exist to resolve conflicts between 
the controlling shareholder and minority shareholders, the equal opportunity rule is a key provision of corporate governance. In contrast to the blockholder system, the dispersed shareholder system is less affected by the introduction of the mandatory bid rule. In order to develop protection for outside investors during transfer of control, European Union countries adopted in 2004 a legal regulation (directive 2004/25/CE on public acquisitions). It introduced provisions such as the equal opportunity rule or the mandatory bid price mechanism (art.5). Both result in a put option, allowing investors to exit at the same selling price as the paid acquisition price. These rules modify the equilibrium in the reallocation of control. For instance, the buyer of a control block may receive an unknown and larger stake of capital from the target firm. This makes the buyer's choice different from situations of unconstrained acquisition of control. This question combines with the fact that the initially acquired block may be different from the stake of capital desired by the new controller.

Introducing corporate governance rules may affect the welfare and the efficiency of corporate control and market discipline (Davies and Hopt, 2004; Goergen et al., 2005). These rules may discourage the current blockholders from accepting an offer. Consequently, the equal opportunity principle is an additional barrier to a well-functioning market for corporate control in a blockholder-based governance regime. Introducing an equal opportunity/mandatory bid rule has implications for ownership and control structure in a blockholder system. First, it makes the blockholder system less efficient, as it reduces the occurrence of trade in controlling blocks, which is the dominant way to transfer control (Burkart et al., 1998; Köke and Renneboog, 2005; Schuster, 2010). Consequently, control may remain in the hands of inefficient blockholders. Second, it restricts the size of the stake a blockholder is allowed to acquire without triggering a tender offer. Third, the higher the bid price in a mandatory tender offer, the lower the acquirer's incentive to make a bid, so ownership and control in the blockholder system are likely to remain concentrated.

A formalized approach is necessary to gain insight into the EOR effect on transfer of control. Bergstrom et al. (1997) developed a theoretical analysis of the effects of the rule on the shareholder's wealth. They partially support the optimality of the Mandatory Bid Rule. This paper will follow a similar approach. The equal opportunity rule is seen as protecting investors in a situation of transfer of control. However, the EOR may prevent socially optimal transactions to occur, as potential acquirers, who can pay the incumbent controller for his limited stake in the company, may not pay the same price to all shareholders of the firm. This 
will reduce the takeover activity and induce efficiency losses. Conversely, EOR is associated with minority investors' protection and it has been empirically shown that M\&A activity is larger in countries where investors' protection is better (Rossi and Volpin, 2004). By raising the overall cost, it may avoid value-destroying transfers of control to develop. However, it may also prevent some value increasing transactions that are allowed in the Market Rule.

Only a few studies are devoted to the technical difference between the two procedures of block trade and public tender offer within a context of private benefits. Transfer of control can be achieved by block trade acquisitions or by public takeover bids (Bolton and von Thadden, (1998); Holmen and Novorozhkin (2007); Boone and Mulherin (2007)). Considering Swedish firms over the period 1986-2001, Holmen, et al. (2007) confirmed that the choice of transfer mode depends on the size of private benefits. Block trades (tender offers) are privileged when the controlling shareholder has a smaller (larger) stake and when private benefits are larger (smaller). However, this empirical study did not seem to take into account the fact that the mandatory bid rule had been introduced in Sweden in 1999.

The analysis of the efficiency of the transfer of control is made by comparing the situation with and without an equal opportunity rule. An efficient transfer of control creates new economic value. Does the equal opportunity rule, which benefits outside shareholders, help or hurt the efficient allocation of control? In comparison with a system with no specific outside investor protection, which one works better? Bebchuk $(1994,1999)$ shows that, in a pure Market Rule system with no protective regulation, the system efficiently protects outside shareholders under two conditions: (i) no private benefits before or after the transfer of control, and (ii) the asymmetry of information at the inception of the transaction disappears with an accounting system that efficiently reports the true economic profit of the firm. Burkart and Pannunzi (2004) introduced into this framework the future private benefits levied by the new controlling shareholder. They show that the condition for a transfer of control under the EOR is more demanding than the simple economic efficiency constraint. It leads to the ruling out of some efficient transfers of control. The EOR system reallocates some part of the gain ensuing from the transfer of control to minority shareholders. Moreover, it protects them from inefficient transfers of control. Even if new controlling blockholders continue to appropriate privately a proportion of the benefits, they must offer a higher price to the former controlling 
shareholder in order to satisfy the constraint imposed by the EOR. The above analysis is developed from a macro behavioral point of view. It is affected by several limits:

- The size of the control block is supposedly fixed. No flexibility is offered. It should be considered as an endogenous variable. The new controlling shareholder may aim at an optimal percentage participation stake, which is not the same as the size of the block trade.

- The appropriation rate is also exogenously set at a country level. In fact, it is a negotiated element of the deal.

- We need to explore further the asymmetry of information between the buyer and the seller. Does the new controlling blockholder accurately estimate private benefits levied by the previous one?

- According to Bebchuk (1994) or Burkart and Panunzi (2004), the EOR exit option is totally exercised by minority shareholders. They do not explain the puzzle of a partial exercise of this option.

- Linked with the above point, there will remain some minority shareholders after the takeover. They know rationally that they will be exposed to a new uncertain hazard: the future expropriation of private benefits by the new controlling shareholder. In a rational framework, their decisions will ex ante take this risk into account. The above analyses focus on the calculus of the buyers and sellers of control (also Burkart et al. 2000). Nothing is said about the behavior of rational minor shareholders.

\section{Setting a contracting model}

Similarly, to Albuquerque and Schroth (2010), we stand in the private phase of the acquisition process. We consider that the incumbent controller has agreed to sell its stake of capital. We analyze the equal opportunity rule for outside shareholders in a non-hostile takeover context. During the remaining time of the offer, outside shareholders make their choices by considering that the tender offer has been a success. Similarly, they know that a new controller has bought the controlling block. The minor shareholder knows that he has to consider different value for the newly controlled firm. They look forward to the future uncertain profitability of the newly controlled firm. These situations are frequent, corresponding to friendly takeover bids where success is known or quasi-certain from the beginning. This is also the case for many raider bids. Very often, institutional investors make public their decision to accept the public 
offer. Therefore, it is possible to know the evolution of the part of the capital that accepts the bid. With a raider's bid, outside shareholders benefit from a price guarantee when the success is rapidly known, which means before the end of the procedure. The acquisition price is set in the private first part of the acquisitions process. We will consider it as endogenous in the model because it sets the level at which EOR gives outside shareholders an exit option. It is only if the offer is hostile and uncertain up to the end of the procedure that shareholders do not know whether they will benefit from a price guarantee mechanism. Such situations are uncommon (Boone and Mulherin, 2007).

Outside shareholders are aware that control of the firm has just moved toward a new controlling shareholder. They are not naïve. Outside shareholders know that the offer is successful and that they benefit from an equal opportunity rule for one of the following two reasons: (i) there is an explicit price guarantee due to regulation or (ii) there is an implicit price guarantee because the success of the tender offer is quasi-certain and is a mandatory unconditional $100 \%$ equity acquisition. ${ }^{1}$ Under such conditions, the partial use of the exit price opportunity appears as the result of a rational economic calculation. Outside investors will question their optimal ownership according to the future economic profitability of the firm or to the appropriation policy of the new controlling blockholder. Looking at signals is a way to reach ownership equilibrium. In order to analyze better the consequences of the equal opportunity rule, we need to take into account the information asymmetry existing between the new controlling shareholders and outside investors. The outside investors want to know more about the future prospects of the firm.

Private benefits are important in our framework. They are not only European or Asiatic features. As identified by Bebchuk (1999), acquisition premium is a way to assess the rent of control of the exiting controlling shareholder and to buy it out. The market for the transfer of control is also a market in which to exchange private benefits. Traditionally, the acquisition price is presented as the payment for lost benefits to the exiting controlling shareholder. On theoretical grounds (Grossman and Hart, 1980), takeovers would be rare without private benefits. Introducing a mandatory equality gives outside investors access to that price. Nevertheless, looking at the past is not the key point in a deal. Outside investors with an exit

\footnotetext{
${ }^{1}$ Our model applies not only in a legal environment of EOR but also in a Market Rule system if a firm voluntarily decides to implement a price guarantee mechanism by announcing an unconditional 100\% equity tender at the same bid price.
} 
option at the acquisition price are facing a double question: What will be the future economic return of the newly controlled firm and what will be the future private benefits levied by the new controlling shareholders? Investors have to be considered as risk averse because the future economic return is uncertain. The appropriation rate of the new controlling shareholder is a key variable in the setting and is endogenously determined in the transfer of control process.

We need to explain the partial use of the exit opportunity given to outside shareholders in an EOR system. We acknowledge that the acquirer will not buy $100 \%$ of the capital of the target firm as assumed in the Bebchuk (1994) or Burkart and Panunzi (2004) frameworks. The final stake in the capital is an endogenous variable resulting from the minority shareholders' choice. However this choice is also conditioned by the acquirer, who may adapt his offer and his delivered information to target an optimal participation stake at the end of the takeover.

The gap in information between the new controlling shareholder, who knows the future prospects of the firm better than do outside shareholders (who may opt out according to the information they are given), is crucial. It explains the ex post sharing of capital of the target firm after the takeover. We develop a joint equilibrium model within a two-party signaling negotiation based on ex ante expectations. The new controlling shareholder will aim at an optimal participation stake in the target firm. He uses signaling variables to influence the outside investors and, beyond them, the market. Following Leland and Pyle (1977), we know that the fraction of capital targeted by the controlling investor is a sound signal of the profitability of the investment projects of the firm. Minority shareholders will use the exit opportunity following the information they infer from the signal about the future prospects of the firm under its new management.

A situation of asymmetry of information exists because outside investors do not know the true future economic profitability of the firm after takeover and they ignore the amount of private benefits levied by the new controller. A joint signaling model highlights the importance of information and will focus on the existence of some auto-limitation mechanisms. We conjecture that these mechanisms are specific to the EOR system

We use the following variables:

A: bid offer price

$\alpha_{0}$ : initial controlling block bought from the former controlling shareholder or accepting the bid price at the end of the private phase of a takeover process 
$\alpha$ : percentage of shares acquired by the new controller when the transfer of control is completed

$t$ : appropriation rate of private benefits

$V_{S}$ : value of the firm before the takeover

$V_{e}$ : invested economic capital

$B_{S}$ : value of the private benefits of the selling controlling shareholder

$k$ : risk adjusted cost of capital

The value of the firm before the transfer of control $V_{S}$ is the sum of the wealth of the incumbent controlling shareholder, $W_{S}$, and the outside investors' wealth, $W_{O}$. Before the deal, it is equal to the invested economic capital $V_{e}$ multiplied by the economic return on invested capital, $r_{e}{ }^{S}$. This return is an uncertain variable forecasted from the former controlling shareholder's strategic choices. We identify $t_{S}$ with the forecast appropriation rate levied by the former blockholder ${ }^{2}$ :

$$
V_{S}=W_{S}+W_{O}=\left(V_{S}-B_{S}\right)+B_{S}=\underbrace{\frac{V_{e} \cdot\left(r_{e}^{S}-t_{S}\right)}{k}}_{\text {publicmarket value }}+\underbrace{\frac{V_{e} \cdot t_{S}}{k}}_{\text {privatebenefits }}
$$

The initiator looks for control through a target participation stake of $\alpha$ by proposing a bid price $A$. This price integrates the buyout of the selling shareholder's private benefits. It should be above the minimum condition for the previous controlling shareholder to accept to sell. In a context without an EOR rule, the new shareholder buys an initial stake of capital $\alpha_{0}$. The incentive for the incumbent blockholder to sell is:

$$
\alpha_{0} \cdot A \geq \alpha_{0} \cdot\left(V_{S}-B_{S}\right)+B_{S}
$$

This condition means that the price paid to the incumbent controlling shareholder covers (at least) his share of the public value of the firm and his private benefits. It is supposed satisfied and the transfer of control occursAs in Burkart et al. (2000) and Albuquerque and

\footnotetext{
${ }^{2}$ This formula apparently means that benefits extraction entails no specific costs borne by the controlling shareholder. These costs are in a trade-off with the amount of private benefits. They are a function of the investor's stake of capital (Burkart et al., 2000). Without any loss of generality, we assume them to be zero in our comparison between the "without" and "with" EOR context. A more complete model introducing marginally increasing specific costs borne by the controlling shareholder leads to similar results.. We recognize that, looking at (1), the absence of specific cost favours maximum appropriation behaviour by the controlling blockholder.
} 
Schrot (2010), we suppose that an initial stage of negotiations has developed between the incumbent and the new controlling shareholders. The rationale of signaling and the implicit contract between the new controlling shareholder and outside investors is only exogenously constrained by values of $A$ and $\alpha$ satisfying (2). The target stake of capital of the new controlling shareholder and the acquisition price may thus be endogenously set in the equilibrium model. We introduce $\lambda$ as the increase of value captured by the previous controlling shareholder so that he is paid above the minimum binding price including his former private benefits. From (2):

$$
\alpha_{0} \cdot A=\lambda\left[\alpha_{0} .\left(V_{S}-B_{S}\right)+B_{S}\right]
$$

The new controlling shareholder has to buy out the previous owner's private benefits. The incentive condition holds for any $\lambda>1$. This parameter expresses the part of future profits of the firm captured by the previous controlling shareholder. In an EOR context, the new controlling shareholder extends that price to any other shareholders. The setting of the initial transfer of control, particularly the price $\mathrm{A}$, is left undefined and depends on the free variable $\lambda$. The only condition for a signaling equilibrium between the new controlling shareholder and the outside investors is (2). Particularly, the acquirer has partial discretion on A and the targeted participation stake $\alpha$ is not set equal to $\alpha_{0}$ because the control changed. The acquisition premium which is paid over the previous public market value of the firm is:

$$
A=\underbrace{\left(V_{S}-B_{S}\right)}_{\text {Marketvalue }}+\underbrace{\left[(\lambda-1)\left(V_{S}-B_{S}\right)+\frac{\lambda}{\alpha_{0}} B_{s}\right]}_{\text {Acquisistion premium }}
$$

For $\lambda=1$, the minimum incentive condition of the seller is just satisfied and if $\alpha=1$ the new controlling shareholder will minimize the acquisition premium which is then equal to $B_{s}$. The minimum acceptable value for the acquisition price is then $V_{s}$, the global economic value before the takeover.

We do not assume that the new value of the firm is constant, $V_{S}=W_{0}+W_{S}$ is the previous value resulting from the incumbent blockholder's management. A new value $V_{S}^{*}$ results from the new controlling shareholder who develops a different economic project. It has a profitability $r_{e}$ different from the previous $r_{e}^{S}$, and a new appropriation rate $t_{A}$ different from $t_{S}$. Particularly, 
we can assume that $r_{e}$ is higher to make the transfer of control efficient. The previous appropriation state of private benefits was efficient in its specific context of economic return. The (optimal) ownership then was $\alpha_{0}$. Equations 3 and 4 will insure continuity between the former situation and the new one. A new efficient appropriation state follows the transfer of control. It introduces a new implicit contract between the new controller and the remaining outside investors. Particularly the new (efficient) appropriation rate is endogenous and should be determined conditionally on $r_{e}$ and $\alpha$.

The wealth of the new controlling shareholder will depend on the average future economic return on invested capital ensuing from the new management, $r_{e}$, and from the future appropriation rate $t_{A}$. It also depends on his equity stake $\alpha^{3}$. The value of $r_{e}$ is private information of the new controlling shareholder.

$$
\tilde{W}_{A}=\alpha \frac{V_{e} \cdot\left(r_{e}+\tilde{x}-t_{A}\right)}{k}+\frac{V_{e} \cdot t_{A}}{k}-\alpha \cdot A
$$

Equation (5) says that the acquirer offers a uniform price A to any shareholder. This is for instance a takeover offer with a unique price. We rule out two-tiered offers. Non discriminating unconditional price are usual in the European context and are considered in the Burkart et al. (2004) model. The shares are offered by the incumbent controller $\alpha_{0}$ and some minority investors, summing up to $\alpha$. Without EOR the acquirers can target a $\alpha^{*}$ stake of capital. If the total number of shares offered excesses $\alpha^{*}$, the common Market Rule sets that a proportional reduction should applies in the tender offer. In private block trades, the $\alpha^{*}$ stake is obtained through the block trade plus complementary share bought in the market. The new controlling shareholder knows the average value $r_{e}$ but the economic profitability is exposed to an error term $\tilde{x}$ such that $E(x)=0$. We assume the economic uncertainty to be normal with standard deviation $\sigma_{x}$. Controlling and outside investors share the same information on $\sigma_{x}$. Outside investors remaining in the firm do not know the true value $t_{A}$. However, they know that $t_{A}$ is lower than $r_{e}$, which means that no default is considered in the setting. The new controlling blockholder looks for appropriating private benefits in a long-term (infinite) perspective and does not want the firm to go bankrupt. The parameter $t_{A}$ is set by the new blockholder. The

\footnotetext{
${ }^{3}$ The controlling shareholder bears some specific agency costs. They should be subtracted from the private benefits. Without any loss of generality, our model assumes that theses costs are null. A complete version introducing costs marginally increasing with benefits extraction leads to similar conclusions. See footnote (1).
} 
outside shareholders will forecast the future values of the economic profitability and of the appropriation rate and will receive information from the controlling shareholder. We define their forecast as functions of parameters of the delivered information, $r_{e}($.$) and t_{A}($.$) . The value$ of the outside investors' stake in the firm is:

$$
\tilde{W}_{0}=(1-\alpha) \cdot \frac{V_{e}\left(r_{e}(.)+\tilde{x}-t_{A}(.)\right)}{k}
$$

The acquirer's problem includes the outside investors conditional belief about the average post takeover profitability $r_{e}($.). The former values his portfolio of shares according the public market value of shares. In the market, the price is made by minor investors using theirs beliefs even if these beliefs are different from the true economic profitability $r_{e}$ (made uncertain by $x$ ), which is known by the new controlling shareholder. He faces an optimisation problem because his wealth is based by the appraisal by the market of the future economic return which yields the security value of the share. Using A, the acquirer will deliver a signal. Outside shareholders remaining after the takeover know that private appropriation exists and that the rate $t_{A}$ is a function of $\alpha$ and of $\mathrm{A}$. These two signals are identified by the market and are integrated into the valuation by market participants. Asymmetries of information exist about the economic return and the appropriation rate. The controller sets the value of $t_{A}$ and knows $r_{e}$ better. Outside investors will only infer these parameters through the price A and the stake $\alpha$. In our framework, the market value is set by outside investors who will consider these two signals in order to build their forecast. The acquirer chooses two values as signals and outside investors set their own $\left[r_{e}(\alpha, A), t_{A}(\alpha, A)\right]$. The future economic return is uncertain and represents from the outside investors' point of view a hazard due to economic noise such that $E(x)=0$.

The incentive to set up is not seen from the acquirer's side but from the outside investors' side. In an EOR context, the problem is not to buy out minority shareholders, but for the later to sell out their shares. In setting his optimal target stake $\alpha^{*}$, the acquirer has to integrate the optimum sell out choice of the outside investors using their EOR exit opportunity. Knowing that he has to monitor the stake of capital sold out by minor investors, $\alpha \mathrm{g}$, the acquirer needs to acquire supplementary shares from the minority shareholder above what he gets from the EOR rule. So to target his optimal final stake, he has to find an optimal stake $\alpha^{*}$, which may be different from what he bought from the incumbent controller $\alpha_{0}$ and from the outside investors, $\alpha_{g}$. The acquirer will choose the values of $\alpha$ and $A$, which will maximize his 
expected utility of wealth. He knows that his optimal choice will induce a market valuation based on implicit values for $r_{e}$ and $t_{A}$ :

$$
\begin{aligned}
& \alpha^{*}=\alpha^{*}\left(r_{e}^{*}, t_{A}^{*}\right) \\
& A^{*}=A^{*}\left(r_{e}^{*}, t_{A}^{*}\right)
\end{aligned}
$$

It is known that the economic profitability as perceived by the market is an increasing function of alpha, $r_{e}(\alpha)$ (Leland and Pyle,1977). A joint equilibrium schedule will imply that the valuation is based on a fair appraisal by the market of the true values of $r_{e}$ and $t_{A}$. This valuation is done using the public signal values $\alpha$ and $A$. Reversing the equations at market equilibrium gives:

$$
\begin{aligned}
& r_{e}\left[\alpha^{*}(., .), A^{*}(., .)\right]=r_{e}{ }^{*} \\
& t_{A}\left[\alpha^{*}(., .), A^{*}(., .)\right]=t_{A}{ }^{*}
\end{aligned}
$$

If, for instance, the value $r_{e}(\alpha, A)$ used by the outside investors and the market were greater than the true value of $r_{e}$ (only known by the new controlling shareholder), the stock market value would be over-valued and, in the end, outside investors would receive less than the required expected risk adjusted return on the market (Leland and Pyle, 1977, p.374). In an infinite constant cash-flow valuation, at equilibrium, the numerator of the market public value is the equalized net economic return: $r_{e}()-.t_{A}()=.r_{e}^{*}-t_{A}^{*}$. The valuation of the firm in the market is the same considered by each category of shareholder in order to optimize their wealth. Compared with the Burkart et al. (2000) model, we refer to the same observable variables (acquisition premium, block size) to infer unobservable variables such as the appropriation rate or private benefits. The difference is that we stay in the process of negotiation just before the public phase of the transfer of control. Burkart et al. (2000) need to know the stock price change around the transfer of control. We do not. It allows us to model a transaction process compatible either with a block trade or a takeover bid process (Boone and Mulherin, 2007). 


\section{Contracting without EOR}

In a system without the equal opportunity rule, we maximize the controlling shareholder's net wealth. The existence of economic uncertainty enhances the investor's risk aversion. We introduce a utility function of wealth $U($.$) and consider the expected utility of$ wealth. Using equation (5) the net wealth of the new controlling shareholder is with $r_{e}($.$) and$ $t_{A}($.$) set at their optimum:$

$$
\tilde{W}_{A}=\alpha \frac{V_{e} \cdot\left(r_{e}(.)+\tilde{x}-t_{A}(.)\right)}{k}+\frac{V_{e} \cdot t_{A}(.)}{k}-\alpha . A
$$

In order to optimize, we set the first derivative to zero with respect to the two signals. Deriving versus the acquisition price $A$, we obtain:

$$
\frac{d E\left[U\left(W_{A}\right)\right]}{d A}=E\left\{U^{\prime}\left(W_{A}\right) \cdot\left[\frac{\alpha \cdot V_{e}}{k}\left(\frac{d r_{e}(.)}{d A}-\frac{d t(.)}{d A}\right)+\frac{V_{e}}{k} \frac{d t(.)}{d A}-\alpha\right]\right\}=0
$$

Equivalently:

$$
\alpha \frac{. V_{e}}{k}\left(\frac{d r_{e}(.)}{d A}\right)+(1-\alpha) \frac{. V_{e}}{k}\left(\frac{d t(.)}{d A}\right)=\frac{\alpha \cdot E\left[U^{\prime}\left(W_{A}\right)\right]}{E\left[U^{\prime}\left(W_{A}\right)\right]}=\alpha>0
$$

And:

$$
\left(\frac{d r_{e}(.)}{d A}\right)+\frac{(1-\alpha)}{\alpha}\left(\frac{d t(.)}{d A}\right)=\frac{k}{V_{e}}>0
$$

If $\alpha=1$, equation (10) simplifies and we get $d r_{e}(.) / d A=k / V_{e}$. This expression is positive: if the acquirer proposes a high acquisition price $A$ he issues a positive signal on the future economic return of the target firm. From that binding limit, equation (10) simplifies because $d t(.) / d A$ should be null in order to be equal to $k / V_{e}$, whatever the value of $\alpha$. As a consequence, the expropriation rate forecasted by outside investors is not linked with the value of the acquisition price $A$. Economically, considered from the new controlling shareholder's point of view, the acquisition price $A$ pays for the past private benefits and is a pure signal for the future economic return. It does not depend on the future private expropriation.

If we set the acquisition price as equal to the minimum acceptable value $V_{s}$ for a transfer of control to occur, we get: $A=V_{S}=V_{e} r_{e}^{S} / k$, with $r_{e}^{S}$ being the economic profitability of the 
firm under the former controlling blockholder's management. As a result, the previous shareholder will receive only the market value before the transfer cumulated with a control premium equal to the former private benefits. We stand at the limit condition where $\lambda=1$ in equations (3). In that eventuality, the new controlling shareholder does not issue any signal about the future economic return. The price just satisfies the transfer condition and nothing more is given because the future economic return of the firm is the same as the economic return considered before the transfer of control: $r_{e}=r_{e}{ }^{S}$. We now integrate the restricted right hand side of (10), $d r_{e}=\left(k / V_{e}\right) \cdot d A$, over the two variables $r_{e}$ and $A$ and use the previous limit condition $r_{e}=r_{e}^{S}$ (for $A=V s$ ). We get a relation where the future economic return of the firm after a transfer of control is a linear form of $\left(A-V_{e} \cdot r_{e}^{S} / k\right)$. This last variable is the control premium. ${ }^{4}$ It is defined as the difference between the acquisition price and the minimum acquisition price to initiate a transfer, which is equal to the former economic value of the firm (i.e. including private benefits, see Figure 1):

$$
r_{e}=r_{e}^{S}+\frac{k}{V_{e}}\left(A-\frac{V_{e} \cdot r_{e}^{S}}{k}\right)
$$

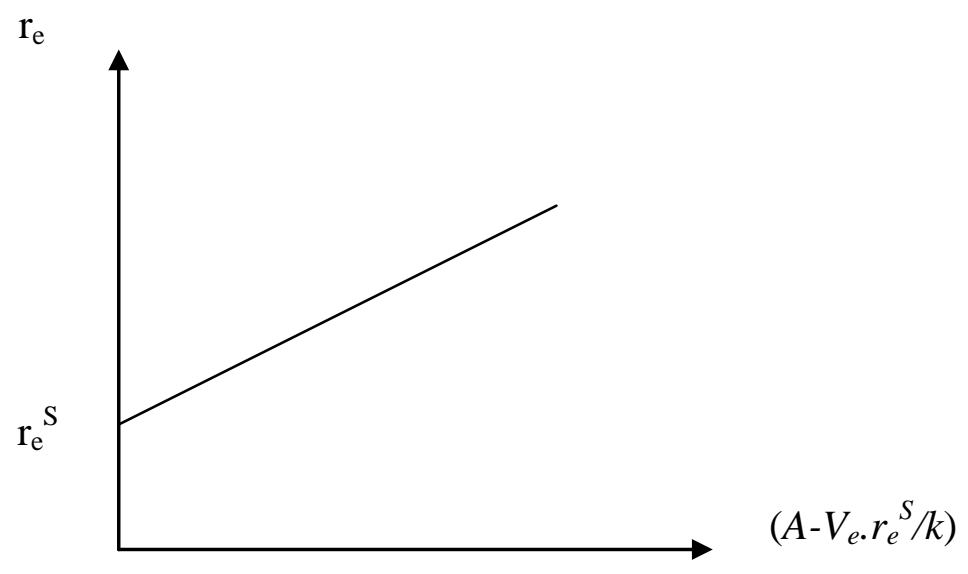

Figure 1: Relationship between the expected economic return and the control premium

The relationship $r_{e}(\alpha, A$, ) increases linearly with the control premium. The higher the acquisition price, the higher the expected future economic return as perceived by outside shareholders. Moreover, the acquisition price is a useless piece of information to anticipate the future expropriation rate of the new controlling shareholder. Outside investors know that the

\footnotetext{
${ }^{4}$ Using (4) we get the control premium: $A-V_{S}=\left[(\lambda-1)\left(V_{S}-B_{S}\right)+\frac{\lambda-\alpha_{0}}{\alpha_{0}} B_{S}\right]$
} 
acquisition price is a pure signal in the sense that it will only reveal future economic profitability after a transfer of control.

The acquirer's optimization with regard to the ownership stake $\alpha$ in the target firm gives:

$$
\begin{aligned}
& \frac{d E\left[U\left(\tilde{W}_{A}\right)\right]}{d \alpha}= \\
& E\left\{U^{\prime}\left(\tilde{W}_{A}\right)\left[\frac{V_{e}}{k}\left(r_{e}(.)+\tilde{x}-t_{A}(.)\right)-A+\alpha \cdot \frac{V_{e}}{k}\left(\frac{d r_{e}(.)}{d \alpha}-\frac{d t_{A}(.)}{d \alpha}\right)+\frac{V_{e}}{k} \frac{d t_{A}(.)}{d \alpha}\right]\right\}=0
\end{aligned}
$$

In the expected value, we identify a product because $W_{A}$ and $x$ are random variables. It leads to a covariance term ${ }^{5}$ :

$$
\alpha \frac{V_{e}}{k}\left(\frac{d r_{e}(.)}{d \alpha}\right)+(1-\alpha) \frac{V_{e}}{k}\left(\frac{d t_{A}(.)}{d \alpha}\right)=-\frac{E\left[U^{\prime \prime}\left(\tilde{W}_{A}\right)\right] \operatorname{cov}\left(\tilde{W}_{A}, \frac{V_{e}}{k} \cdot(\tilde{x})\right)}{E\left[U^{\prime}\left(\tilde{W}_{A}\right)\right]}+\left[\frac{V_{e}}{k}\left(r_{e}(.)-t_{A}(.)\right)-A\right]
$$

Introducing (8) and manipulating the covariance term gives:

$$
\operatorname{cov}\left[\tilde{W}_{A}, \frac{V_{e}}{k}(\tilde{x})\right]=\operatorname{cov}\left[\frac{\alpha \cdot V_{e}}{k}(\tilde{x}), \frac{V_{e}}{k}(\tilde{x})\right]=\alpha\left(\frac{V_{e}}{k}\right)^{2} \sigma_{x}^{2}
$$

Using $\mu$ as a (positive) equivalent risk aversion coefficient, we state that $E\left[U^{\prime \prime}().\right] / E\left[U^{\prime}().\right]=-1 / \mu$.

$$
\alpha\left(\frac{d r_{e}(.)}{d \alpha}\right)+(1-\alpha)\left(\frac{d t(.)}{d \alpha}\right)=\frac{1}{\mu} \cdot \alpha\left(\frac{V_{e}}{k}\right) \sigma_{x}^{2}-\left[\left(r_{e}(.)-t_{A}(.)\right)-\frac{k}{V_{e}} A\right]
$$

In order to solve the differential equation (13) we posit an additional hypothesis on the relationship between $t$ and $\alpha$. We assume a negative linear relationship. The idea is that the controlling shareholder is less incited to expropriate as he gains more capital ownership (see Lemma 1, Burkart et al., 1998, 2000). The Jensen's incentive effect is supposed to hold as benefits decrease with ownership concentration. At the limit, if the controller owns $100 \%$ of the equity capital he is indifferent to a choice between private and public benefits. ${ }^{6}$ The negative relationship exists between the ownership stake and the private appropriation rate is known by

\footnotetext{
${ }^{5}$ Remembering that for normal variables: $\operatorname{cov}(f(x), y)=f^{\prime}(x) \cdot \operatorname{cov}(x, y)$

${ }^{6}$ Assuming no difference in tax treatment.
} 
the controller. He uses it to derive his optimal appropriation. The outside investors know only that a decreasing function exists and know its sign. However, it is not public information and they do not know its exact form. Asymmetry of information exists about the appropriation rate $t_{A}$. The controller sets its value. Outside investors will only infer it, and know that the fair signal for it is $\alpha$. A high value of $\alpha$ is a "commitment" to extract fewer private benefits. But the ex ante type of controller with regard to private benefits expropriation is not known because it depends on the target $\alpha^{*}$ to be optimized. In the EOR context, it will depend both on $\alpha$ and $\alpha_{\mathrm{g}}$ which itself depend on the outside investors' choice (see below).

We set:

$$
t_{A}=\gamma_{0}-\gamma_{1} \alpha
$$

The appropriation relationship (14) is only defined for values of ownership $\alpha$ higher than the threshold level $\alpha_{\min }$ to take over control of the firm (and for values lower than 100\%). For $\alpha=100 \%$, the appropriation rate is zero, so: $\gamma_{0}=\gamma_{1}=\gamma>0$ (see Figure 2).

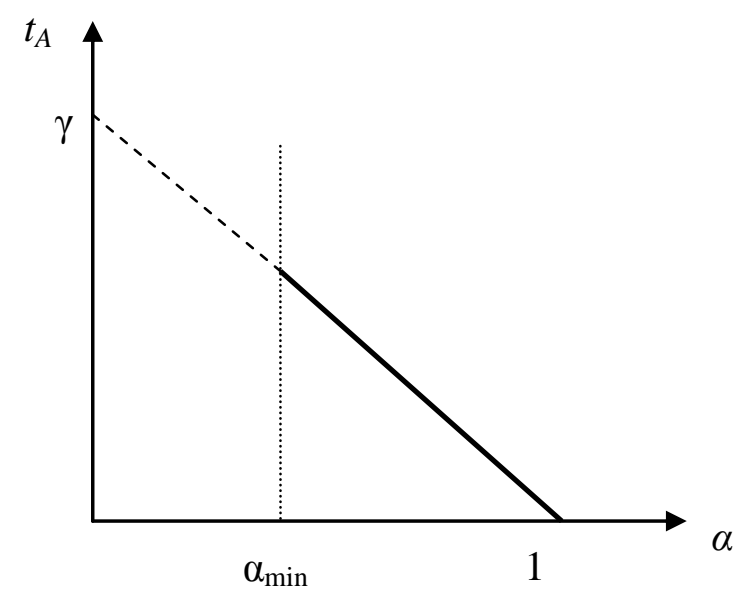

Figure 2: Relationship between appropriation rate and ownership stake of capital of the controlling blockholder 
Applying (14) to (13) gives:

$\frac{d r_{e}(.)}{d \alpha}=\frac{2 .(1-\alpha)}{\alpha} \gamma-\frac{\left(r_{e}(.)-\frac{A . k}{V_{e}}\right)}{\alpha}+\frac{1}{\mu}\left(\frac{V_{e}}{k}\right) \sigma_{x}^{2}$

Equivalent to:

$\frac{d r_{e}(.)}{d \alpha}+\frac{r_{e}(.)}{\alpha}=\frac{\left(2 \gamma+\frac{A . k}{V_{e}}\right)}{\alpha}-2 \gamma+\frac{1}{\mu}\left(\frac{V_{e}}{k}\right) \sigma_{x}^{2}$

The right hand side of (15) is positive (with $\alpha$ set between 0 and 1). Therefore, the left hand side is also positive. Because of $r_{e}(.) / \alpha$ being positive, we get an unknown sign of the derivative between an increase in the ownership stake of the controlling blockholder and the evolution of the future economic return of the target firm. The solution of the differential equation (15) is (see Annex):

$$
r_{e}(\alpha)=\left(2 \gamma+\frac{A \cdot k}{V_{e}}\right)+\left[\frac{1}{\mu}\left(\frac{V_{e}}{k}\right) \sigma_{x}^{2}-2 \gamma\right] \frac{\alpha}{2}+\frac{c}{\alpha}
$$

Equation (16) defines a family of curves according the values of the integration constant $c$ (see Figure 3). Recalling that the derivative of $r_{e}$ versus $\alpha$ should be positive in order to deliver a sound signal of increasing profitability with the stake in capital belonging to the controlling shareholder, the following sufficient condition needs to be satisfied: $\left[\frac{1}{\mu}\left(\frac{V_{e}}{k}\right)\left(\sigma_{x}^{2}\right)-2 \gamma\right]>0$ (with $c$ negative). The last part of the equation is not binding, since $c$ can take any value. The first part of the right hand side of equation (16) imposes an upside limit on the appropriation ratio. 


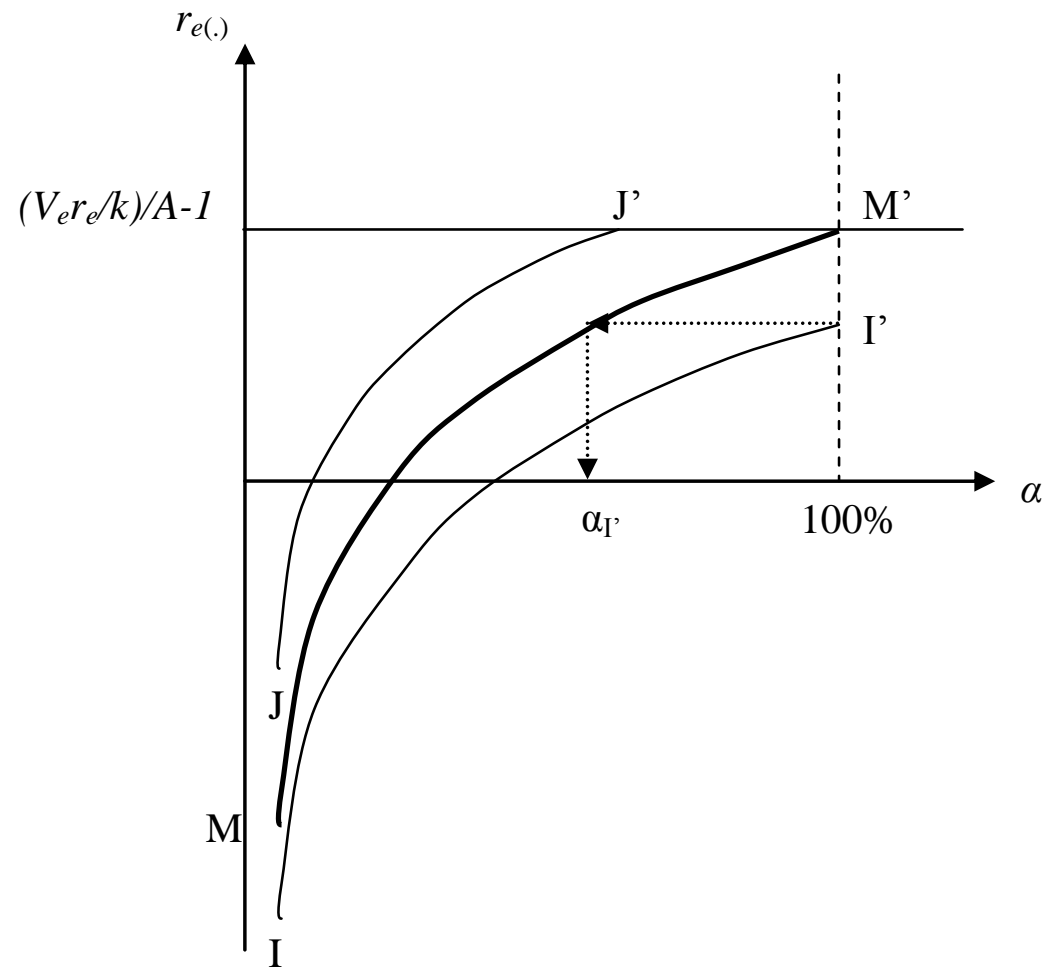

Figure 3: Situations of the new controlling shareholder

For the limit value $\alpha=1$, equation (16) gives: $r_{e}(1, A)=\left(2 \gamma+\frac{A \cdot k}{V_{e}}\right)+\left[\frac{1}{\mu}\left(\frac{V_{e}}{k}\right) \sigma_{x}^{2}-2 \gamma\right] \frac{1}{2}+c$. This case corresponds to a total ownership of the firm by the acquirer. It determines the locus of point in Figure 3 defined by the intersection of the family of curves (16) and the vertical line from $\alpha=100 \%$. Moreover, we know that if the ownership stake is $100 \%$, the controlling shareholder will not expropriate. The value of the firm under the new shareholder's total control and ownership is $V_{e} r_{e}{ }^{*} / k$ with $r_{e}{ }^{*}$ the true economic profitability forecast. His required future investment return is obtained from the ratio of the firm's values after takeover divided by the acquisition price minus $1: \frac{V_{e} r_{e}^{*} / k}{A}-1$. Substituting, in $r_{e}(1, A)$, we identify the point $\mathrm{M}^{\prime}$ by setting the constant value equal to: $c=\frac{V_{e} r_{e}^{*} / k}{A}-1-\gamma-\frac{A \cdot k}{V_{e}}-\frac{1}{2}\left[\frac{1}{\mu}\left(\frac{V_{e}}{k}\right)\left(\sigma_{x}^{2}\right)\right] \cdot{ }^{7}$ As a result, the acquirer's announced future return

\footnotetext{
${ }^{7}$ The sufficient negative condition on $c$ is therefore equivalent to $\frac{r_{e}^{*}}{k}<\frac{A}{V_{e}}(1+\gamma)+\left(\frac{A}{V_{e}}\right)^{2} k+\frac{1}{2} \frac{A}{V_{e}}\left[\frac{1}{\mu}\left(\frac{V_{e}}{k}\right)\left(\sigma_{x}^{2}\right)\right]$.
}

The right hand side of this inequality is positive. It compares the takeover premium $A / V_{e}$ and the ratio of the expected profitability of the new management divided by the market risk adjusted valuation rate: This condition is 
is effectively: $r_{e}(1, A)=\frac{V_{e} r_{e}^{*} / k}{A}-1$, and the return on his investment is equal to the return of the economic project. Among all the equilibrium curves, the curve MM' cuts across that vertical line at point $\mathrm{M}^{\prime}$.

According to different values of $c$, we can set, for instance, $c<\frac{V_{e} r_{e}^{*} / k}{A}-1-\gamma-\frac{A k}{V_{e}}-\frac{1}{2}\left[\frac{1}{\mu}\left(\frac{V_{e}}{k}\right)\left(\sigma_{x}^{2}\right)\right]$. We then define a point I', which gives $r_{e}(1,)<.\mathrm{M}^{\prime}$. The acquirer may launch a total acquisition with a disclosed $r_{e}()<.\mathrm{M}^{\prime}$; he will receive a return on his investment lower than M'. If he wants to disclose a future economic return $r_{e}$ lower than M', he is better off staying on the equilibrium curve MM', holding an equity stake $\alpha_{I}$, and letting a stake of capital $\left(1-\alpha_{I^{\prime}}\right)$ go to outside shareholders. Even if the controlling blockholder issues a weaker future economic profitability by setting $r_{e}()<.\mathrm{M}^{\prime}$, the private benefits he appropriates will account for the difference. If the new controlling shareholder privileges an equilibrium curve above MM', he may not announce economic returns higher than M'. If he stays at point J', he announces $r_{e}()=.\mathrm{M}^{\prime}$, but he wants to hold only a stake $\alpha$ of the capital. He will not find outside investors in the market to buy the complementary (1- $\alpha$ ) percentage, because minority shareholders will integrate future expropriation into their valuation. The new controlling shareholder is therefore better off setting $r_{e}=\mathrm{M}^{\prime}$ because then he will not suffer from a discount in the market price of his shares resulting from his $100 \%$ ownership.

As a consequence, the MM' curve is the only feasible equilibrium locus set for the new controlling shareholder. Its equation is:

$$
r_{e}=\left(2 \gamma+\frac{A \cdot k}{V_{e}}\right)+\left[\frac{1}{\mu}\left(\frac{V_{e}}{k}\right) \sigma_{x}^{2}-2 \gamma\right] \frac{\alpha}{2}+\frac{1}{\alpha}\left[\frac{V_{e} r_{e}^{*} / k}{A}-1-\gamma-\frac{A k}{V_{e}}-\frac{1}{2}\left[\frac{1}{\mu}\left(\frac{V_{e}}{k}\right)\left(\sigma_{x}^{2}\right)\right]\right]
$$

Through the implicit profitability as forecasted by the market, the new blockholder's stake influences the market value of the firm and his global wealth. The new controller has a large set of choice in a non-EOR context. The equation MM' defines a demand curve for the acquirer. The latter can balance, for instance, a low market valuation due to a small controlling block $\alpha$ with a higher private appropriation through relation (14). Particularly, the targeted stake of equity can be different from $\alpha_{0}$. The situation is simple: if the bid price $\mathrm{A}$ is higher than the 
expected market value based on the future net profitability $r_{e}()-.t_{A}($.$) , all outside shareholder$ will offer their shares and bring $100 \%$ of equity capital to the tender (See eq (8)).

The difference between the post-takeover value and A depends on the size of the appropriation rate $t$. If $t_{A}$ is null, we are in the limit position where the post-takeover value in the market is equal to $A$. The (risk neutral) outside investors are indifferent between tendering their shares and holding them. A limitation rule is the only solution. In the general situation, for a given target ownership stake $\alpha^{*}$ from the controller, we may assume that the share value based on $r_{e}()-t()$ (for risk neutral investors) is lower that an offer price embedding a acquisition premium. Then, the only way to get an equilibrium is to ration the outside investors by using a proportional rule in such a way that the target $\alpha^{*}$ is reached by the acquirer. If no quantity limitation mechanism is implemented, the acquirer will buy $100 \%$ of the shares, overpay the firm and lose value with regard to his optimum stake. We cannot say that the acquirer will be better off staying with the $\alpha_{0}$ stake bought from the incumbent controller. In such a situation, he may suffer from an opportunity loss. The only way to find equilibrium is to give the acquirer the right to reduce the offer by outside investors.

If we move to the simplified context of Leland and Pyle (1977), where private appropriation does not exist (i.e. $t_{A}=0$ or equivalently $\gamma=0$ ). The ownership stake of the dominant shareholder is the only signal to outside investors. So, relationship (15) simplifies to:

$$
\frac{d r_{e}}{d \alpha}+\frac{r_{e}(.)}{\alpha}=\frac{\left(\frac{A k}{V_{e}}\right)}{\alpha}+\frac{1}{\mu}\left(\frac{V_{e}}{k}\right) \sigma_{x}^{2}
$$

Using (17) and setting $\gamma$ to zero, the solution curve is:

$$
r_{e}=\left(\frac{A \cdot k}{V_{e}}\right)+\left[\frac{1}{\mu}\left(\frac{V_{e}}{k}\right) \sigma_{x}^{2}\right] \frac{\alpha}{2}+\frac{1}{\alpha}\left[\frac{V_{e} r_{e}^{*} / k}{A}-1-\frac{A k}{V_{e}}-\frac{1}{2}\left[\frac{1}{\mu}\left(\frac{V_{e}}{k}\right)\left(\sigma_{x}^{2}\right)\right]\right]
$$

For a total ownership $\alpha=1$, we are in the same situation as previously discussed. The equilibrium curves between the situation with and without private benefits will share the same equilibrium point $M$ ' which gives full $100 \%$ ownership. The equilibrium curve ZM' without 
appropriation (i.e. in a standard dispersed ownership system) is defined by equation (19). It is located above the equilibrium curve $\mathrm{MM}^{\prime}$ in a situation of expropriating controlling shareholders (see Figure 4).

The equilibrium curve with appropriation as defined by equation (17) is logically below that without private benefits. The gap with the curve defined by (19) is explained by the appropriation rate $\gamma$, which enters negatively into the formula (17) in the linear slope term and in the inverse term. Using (17), we see that $d r_{e} / d \gamma$ is strictly negative. This means that, for a given value of $\alpha$ (inferior to 1), the announced future economic profitability $r_{e}$ is lower in a context of private appropriation. Outside shareholders discount the signal by a forecast of private benefits. The quality of the signal increasingly deteriorates as controlling ownership falls. A similar way to express it is to say that, in order to issue a future economic profitability, $r_{e}^{*}$, being identical to the one in a no private benefits environment, the controlling shareholder located on MM' should hold a higher stake in capital in order to compensate for the suspicion of private benefit and to give more strength to the signal coming from $\alpha$ (see Figure 4).

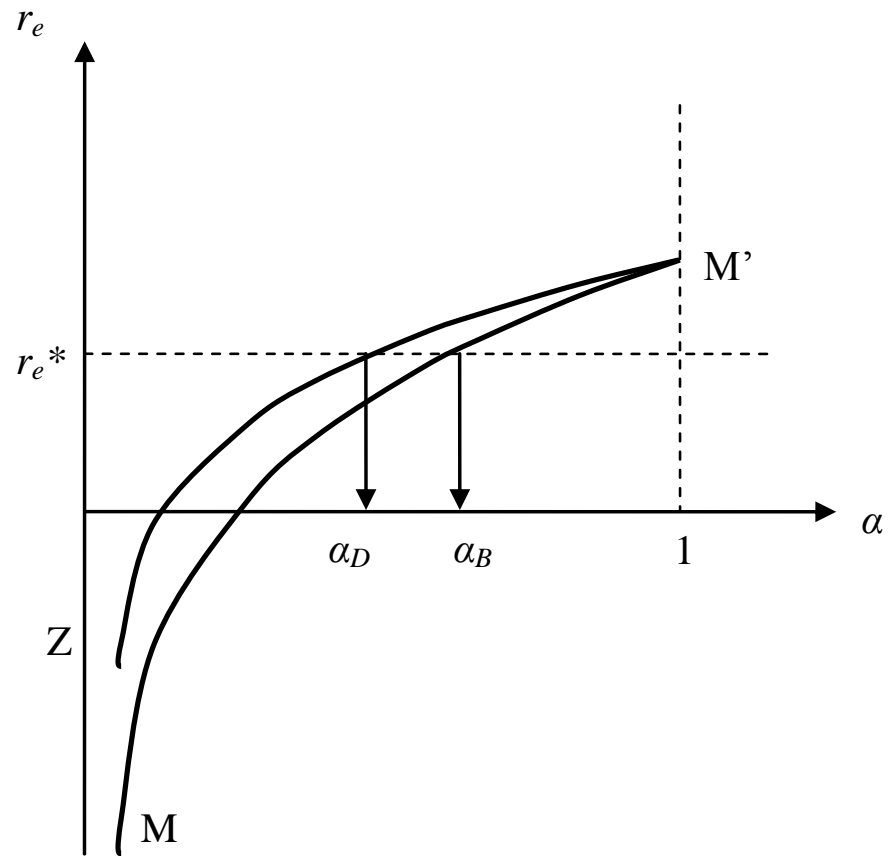

Figure 4: Comparison of the equilibrium curves for acquiring shareholder in dispersed ownership and concentrated ownership 


\section{Contracting with EOR}

We refer now to a situation with an equal opportunity rule. The wealth function of the acquirer should include a new variable $\alpha_{g}$, which is the part of the capital bought by the acquirer as a result of the mandatory bid rule.

$$
\tilde{W}_{A}=\left(\alpha+\tilde{\alpha}_{g}\right) \frac{V_{e}\left(r_{e}(.)+\tilde{x}-t_{A}(.)\right)}{k}+\frac{V_{e} t_{A}}{k}-\left(\alpha+\tilde{\alpha}_{g}\right) A
$$

The new controlling shareholder will optimize the number of shares bought by outside investors through the mandatory bid procedure or the price guarantee mechanism set into force during the takeover. However, he has to take into account the choice of outside investors, as they want to optimize their participation in the firm and compare its value with the exit option granted by the EOR.

\subsection{Outside shareholders' behavior with EOR}

The wealth of outside investors increases with their opportunity to sell out shares at the acquisition price $A$.

$$
\tilde{W}_{o}=\left(1-\alpha-\alpha_{g}\right) \frac{V_{e}\left(r_{e}(.)+\tilde{x}-t_{A}(.)\right)}{k}+\alpha_{g} A
$$

Minor investors can react and optimize from their point of view the value of $\alpha_{g}$. We first need to solve the outside shareholders' problem because the controlling shareholder knows that the proportion of capital he should buy following the EOR depends on the future economic return and on the appropriation rate, both of which are anticipated by minority shareholders through the publicly observed values $\alpha$ and $A$. Setting to zero the derivative of the expected utility with regard to $\alpha_{g}$ yields:

$$
\frac{d E\left[U\left(\tilde{W}_{O}\right)\right]}{d \alpha_{g}}=E\left\{U^{\prime}\left(\tilde{W}_{O}\right)\left[-\frac{V_{e}}{k}\left(r_{e}(.)+\tilde{x}-t_{A}(.)\right)+A-\alpha_{g} \frac{V_{e}}{k}\left(\frac{d r_{e}(.)}{d \alpha_{g}}-\frac{d t_{A}(.)}{d \alpha_{g}}\right)\right]\right\}=0
$$


Manipulating:

$$
\begin{aligned}
{\left[\alpha_{g} \frac{V_{e}}{k}\left(\frac{d r_{e}(.)}{d \alpha_{g}}-\frac{d t_{A}(.)}{d \alpha_{g}}\right)\right] } & =\frac{E\left\{U^{\prime}\left(\tilde{W}_{O}\right)\left[-\frac{V_{e}}{k} \cdot\left(r_{e}(.)+\tilde{x}-t_{A}(.)\right)+A\right]\right\}}{E\left[U^{\prime}\left(\tilde{W}_{O}\right)\right]} \\
& =\frac{E\left[U^{\prime \prime}\left(W_{O}\right)\right] \operatorname{cov}\left(W_{0},-\frac{V_{e}}{k} \tilde{x}\right)}{E\left[U^{\prime}\left(W_{O}\right)\right]}+\left[-\frac{V_{e}}{k} \cdot\left(r_{e}(.)-t_{A}(.)\right)+A\right]
\end{aligned}
$$

Referring to $E\left(U^{\prime \prime} / E\left(U^{\prime}\right)=-1 / \mu\right.$, this is equivalent to:

$$
\left[\alpha_{g}\left(\frac{d r_{e}(.)}{d \alpha_{g}}-\frac{d t_{A}(.)}{d \alpha_{g}}\right)\right]=\frac{1}{\mu}\left(1-\alpha-\alpha_{g}\right)\left(\left(\frac{V_{e}}{k}\right) \sigma_{x}^{2}\right)-\left[\left(r_{e}(.)-t_{A}(.)\right)-A \frac{k}{V_{e}}\right]
$$

We look at $\left(r_{e}-t_{A}\right)$, which is the net profitability announced by the controlling shareholder and used by the outside investors to value their wealth in the market. We get:

$$
\frac{d\left(r_{e}(.)-t_{A}(.)\right)}{d \alpha_{g}}+\frac{\left(r_{e}(.)-t_{A}(.)\right)}{\alpha_{g}}=\frac{1}{\alpha_{g}}\left[\frac{1}{\mu}(1-\alpha)\left(\frac{V_{e}}{k}\right) \sigma_{x}^{2}+\left(\frac{A k}{V_{e}}\right)\right]-\frac{1}{\mu}\left(\frac{V_{e}}{k}\right) \sigma_{x}^{2}
$$

Integrating in a similar way as above gives (see Section3):

$$
\left(r_{e}(.)-t_{A}(.)\right)=\left[\frac{1}{\mu}(1-\alpha)\left(\frac{V_{e}}{k}\right) \sigma_{x}^{2}+\left(\frac{A . k}{V_{e}}\right)\right]-\left[\frac{1}{\mu}\left(\frac{V_{e}}{k}\right) \sigma_{x}^{2}\right] \frac{\alpha_{g}}{2}+\frac{c}{\alpha_{g}}
$$

The two limit conditions to be satisfied by (24) are $\alpha_{g}=(1-\alpha)$, meaning the outside investor can only sell the available shares not initially bought by the new controlling blockholder, and $\alpha_{g}=0$ for very high values of $\left(r_{e}-t_{A}\right)$. Equation (24) defines a family of decreasing curves as long as the integration constant is positive (see Figure 5). These curves have a simple economic meaning: if the expected net economic profitability of the firm is high, the stocks are a good investment and outside shareholders will only use the mandatory bid exit for a small part of their investment. At the limit for extremely good prospects of profitability, outside shareholders will keep all their shares. That gives an asymptotic upward oriented shape to the locus of their choices. 


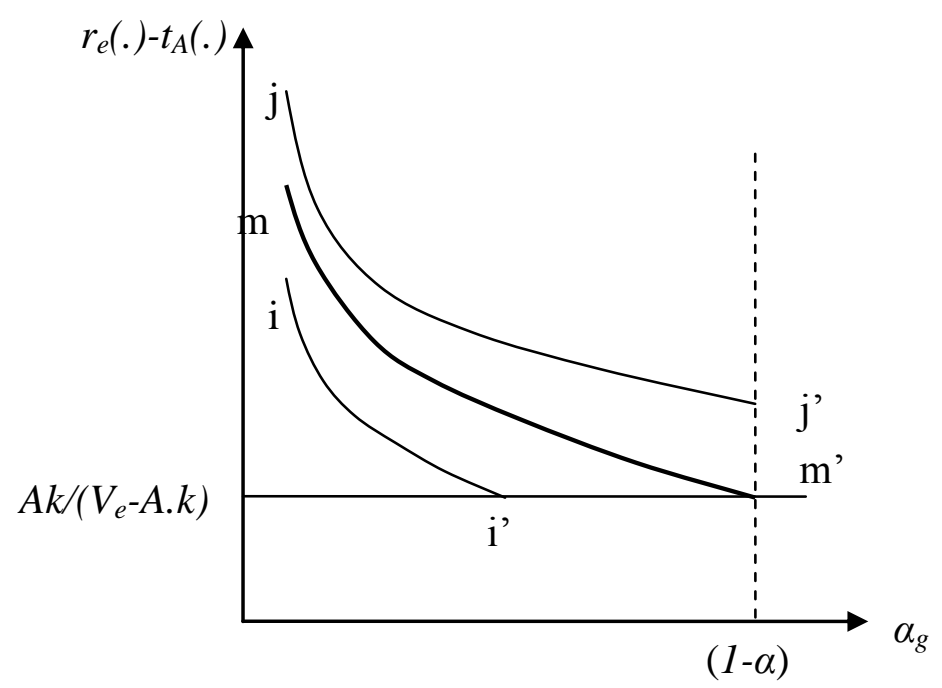

Figure 5: Equilibrium curves of outside shareholders

A specific value of the announced net public profitability $\left(r_{e}-t_{A}\right)$ will result in a return of the investment itself strictly equal to $\left(r_{e}-t_{A}\right)$. It corresponds to $r_{e}()-.t_{A}()=.\frac{V_{e} .\left(r_{e}(.)-t_{A}(.)\right) / k}{A}-1$. This defines a horizontal line $r_{e}()-.t_{A}()=.A k /\left(V_{e}-A k\right)$ in Figure 5. The outside shareholder will not consider any net return below that line. The reverse would mean that the outside investors accept that they will hold shares in the firm with a lower value rather than take the opportunity to sell and exit the firm. We define $m$ ' the the intercept point of that minimum horizontal line located at the specific value $\alpha_{g}=(1-\alpha)$. It specifies one of the curves defined by equation (24). The rationale for it is when the minimum acceptable return is announced to outside investors they will prefer to cash out their shares and exercise totally their exit option. The dominant curve for the choices of minor investors is mm'. That curve is their only set of rational choices. It allows us to determine the value of the integration constant $c=(1-\alpha)\left[\frac{A \cdot k}{V_{e}-A \cdot k}-\frac{A \cdot k}{V_{e}}\right]-\frac{1}{\mu}(1-\alpha)^{2} \frac{V_{e}}{k} \frac{\sigma_{x}^{2}}{2} \cdot{ }^{8}$ For instance, the curve jj' is not acceptable: staying at point j' would mean that outside investors would bring all their shares $\left(\alpha_{g}=(1-\alpha)\right)$ at the exit opportunity, selling them at an acquisition price that is below the market valuation based on the future prospect of profitability they forecast. The equilibrium locus ii' is cut across on its downward curve because of the floor value imposed by the acquisition price. It is also

${ }^{8}$ This is positive for acquisition $A$ prices such that: $\left[\frac{A \cdot k}{V_{e}-A \cdot k}-\frac{A \cdot k}{V_{e}}\right]>\frac{1}{\mu}(1-\alpha)^{2} \frac{V_{e}}{k} \frac{\sigma_{x}^{2}}{2}$ 
dominated by the set of choices resulting from the curves above it. The equation of the mm' curve is:

$$
\begin{aligned}
\left(r_{e}(.)-t_{A}(.)\right) & =\left[\frac{1}{\mu}(1-\alpha)\left(\frac{V_{e}}{k}\right) \sigma_{x}^{2}+\left(\frac{A \cdot k}{V_{e}}\right)\right]-\left[\frac{1}{\mu}\left(\frac{V_{e}}{k}\right) \sigma_{x}^{2}\right] \frac{\alpha_{g}}{2} \\
& +\frac{(1-\alpha)}{\alpha_{g}}\left[\frac{A \cdot k}{V_{e}-A \cdot k}-\frac{A \cdot k}{V_{e}}\right]-\frac{1}{\mu}(1-\alpha)^{2} \frac{V_{e}}{k} \frac{\sigma_{x}^{2}}{2}
\end{aligned}
$$

As an input to equation (25), outside shareholders need to identify the controlling shareholder's targeted stake $\alpha$.

\subsection{Situation of the new controlling shareholder}

Knowing the set of possible rational choices of the outside shareholder, the controlling blockholder will try to optimize his situation. He chooses with regard to the acquisition price, $A$, and the stake of capital he aims to buy on his own, $\alpha$. Setting the derivative of his wealth with regard to $A$ to zero:

$$
\frac{d E\left[U\left(\tilde{W}_{A}\right)\right]}{d A}=E\left\{U^{\prime}\left(\tilde{W}_{A}\right)\left[\frac{\left(\alpha+\alpha_{g}\right) V_{e}}{k}\left(\frac{d r_{e}(.)}{d A}-\frac{d t(.)}{d A}\right)+\frac{V_{e}}{k} \frac{d t(.)}{d A}-\left(\alpha+\alpha_{g}\right)\right]\right\}=0
$$

We get a differential equation close to relationship (10) but introducing explicitly the expected shares to be bought back through the EOR in the acquirer's calculus:

$$
\left(\frac{d r_{e}(.)}{d A}\right)+\frac{\left(1-\alpha-\alpha_{g}\right)}{\left(\alpha+\alpha_{g}\right)}\left(\frac{d t(.)}{d A}\right)=\frac{k}{V_{e}}>0
$$

The analysis we developed earlier regarding the equilibrium locus of choices ensuing from relationship (10) also applies here. The derivative $d r_{e}(.) / d A=k / V_{e}$. is still positive. The existence of an equal opportunity mechanism does not alter the positive relationship between $A$ and the anticipated economic profitability of the target firm after the takeover. The acquisition price is a simple and direct signal of the future economic return of the firm. The linear relation (11) is still valid. The derivative $d t(.) / d A$ remains equal to zero, so the acquisition price does not signal anything about the future appropriation rate. 
Turning now to the optimization of the new controlling shareholder's wealth with regard to $\alpha$, we get:

$$
\begin{aligned}
& \frac{d E\left[U\left(W_{A}\right)\right]}{d \alpha}= \\
& E\left\{U^{\prime}\left(W_{A}\right)\left[\frac{V_{e}}{k} \cdot\left(r_{e}(.)+\tilde{x}-t_{A}(.)\right)-A+\left(\alpha+\alpha_{g}\right) \frac{V_{e}}{k}\left(\frac{d r_{e}(.)}{d \alpha}-\frac{d t_{A}(.)}{d \alpha}\right)+\frac{V_{e}}{k} \frac{d t_{A}(.)}{d \alpha}\right]\right\}=0
\end{aligned}
$$

After some manipulation:

$$
\left(\frac{d r_{e}(.)}{d \alpha}\right)+\frac{\left(1-\alpha-\alpha_{g}\right)}{\left(\alpha+\alpha_{g}\right)}\left(\frac{d t(.)}{d \alpha}\right)=\frac{1}{\mu} \cdot\left(\frac{V_{e}}{k}\right) \cdot \sigma_{x}^{2}-\frac{1}{\alpha}\left[\left(r_{e}(.)-t_{A}(.)\right)-\frac{k}{V_{e}} A\right]
$$

In comparison with a situation without EOR, the coefficient of the $d t(.) / d \alpha$ term is $\left(1-\alpha-\alpha_{g}\right) /\left(\alpha+\alpha_{g}\right)$; this is lower than the one in equation (13), which was $(1-\alpha) /(\alpha)$. For a given increase in $r_{e}$, the new controlling shareholder is driven to expropriate less. Ceteris paribus, for given increases of $r_{e}$ and $\alpha$ at equilibrium, $d t(.) / d \alpha$ is negative. However, in order to compensate, the absolute value of the derivative $d t(.) / d \alpha$ will be higher with EOR than without it. At equilibrium, the appropriation rate $t_{A}$ will decrease more for an increase in $r_{e}$. Consequently, the EOR system is more disciplinary with regard to expropriation.

In order to solve the differential equation (28), we need to add the hypothesis that $d t(.) / d \alpha$ is a negative constant, which implies a linear decreasing function similar to (14) between $t_{A}$ and $\alpha$. We get the differential equation versus $\alpha$ (remembering that $\alpha_{g}$ is a fixed parameter):

$$
\frac{d r_{e}(.)}{d\left(\alpha+\alpha_{g}\right)}+\frac{r_{e}(.)}{\left(\alpha+\alpha_{g}\right)}=\frac{\left(2 \gamma+\gamma \alpha_{g}+\frac{A k}{V_{e}}\right)}{\left(\alpha+\alpha_{g}\right)}-2 \gamma+\frac{1}{\mu}\left(\frac{V_{e}}{k}\right) \sigma_{x}^{2}
$$

The solution of (29) is a family of increasing curves:

$$
r_{e}(\alpha)=\left(2 \gamma+\gamma \alpha_{g}+\frac{A k}{V_{e}}\right)+\left[\frac{1}{\mu}\left(\frac{V_{e}}{k}\right) \sigma_{x}^{2}-2 \gamma\right] \frac{\left(\alpha+\alpha_{g}\right)}{2}+\frac{c}{\left(\alpha+\alpha_{g}\right)}
$$


As previously, we identify a point $M^{\prime}$ for total ownership of capital: $\left(\alpha+\alpha_{g}\right)=1$. This point is the same as the one in the situation without EOR. The only acceptable equilibrium curve is $\mathrm{M}_{\mathrm{EOR}} \mathrm{M}^{\prime}$, shown in Figure 6, and is defined by the equation:

$$
\begin{aligned}
r_{e}= & \left(2 \gamma+\gamma \alpha_{g}+\frac{A k}{V_{e}}\right)+\left[\frac{1}{\mu}\left(\frac{V_{e}}{k}\right) \sigma_{x}^{2}-2 \gamma\right] \cdot \frac{\left(\alpha+\alpha_{g}\right)}{2} \\
& +\frac{1}{\left(\alpha+\alpha_{g}\right)}\left[\frac{V_{e} r_{e}^{*} / k}{A}-1-\gamma-\gamma \alpha_{g}-\frac{A k}{V_{e}}-\frac{1}{2}\left[\frac{1}{\mu}\left(\frac{V_{e}}{k}\right) \sigma_{x}^{2}\right]\right]
\end{aligned}
$$

From the optimization of minority shareholders, $\alpha_{g}$ is either positive or zero. A direct comparison between (31) and (17) shows that the $\mathrm{M}_{\mathrm{EOR}} \mathrm{M}$ ' curve in the "with EOR" case is below the MM' curve without EOR. The difference of implicit economic return $r_{e}($.$) for a given$ set of parameters is $\Delta r_{e}()=.-\gamma \alpha_{g}\left(1-\alpha-\alpha_{g}\right) /\left(\alpha+\alpha_{g}\right)$, which is negative. The system with EOR leads to lower quality information than in a situation without price guarantee protection. A given signal $\alpha$ is more trustworthy and is better perceived by outside shareholders in a no equal opportunity system. For a given value of the signal, the EOR rule weakens the informative situation of outside shareholders in a blockholding system. In order to balance this weakness, the controlling shareholder should issue a stronger or a different signal. His behavior is modified: if he wants to signal a given level of future economic profitability, he needs to buy or to bid for a more important ownership stake within EOR than he does without EOR. We should obviously add that the signaled $r_{e}($.$) needs to be higher than the risk adjusted cost of capital, k$, otherwise the new controlling shareholder would not be encouraged to launch the takeover (see Figure 6). 


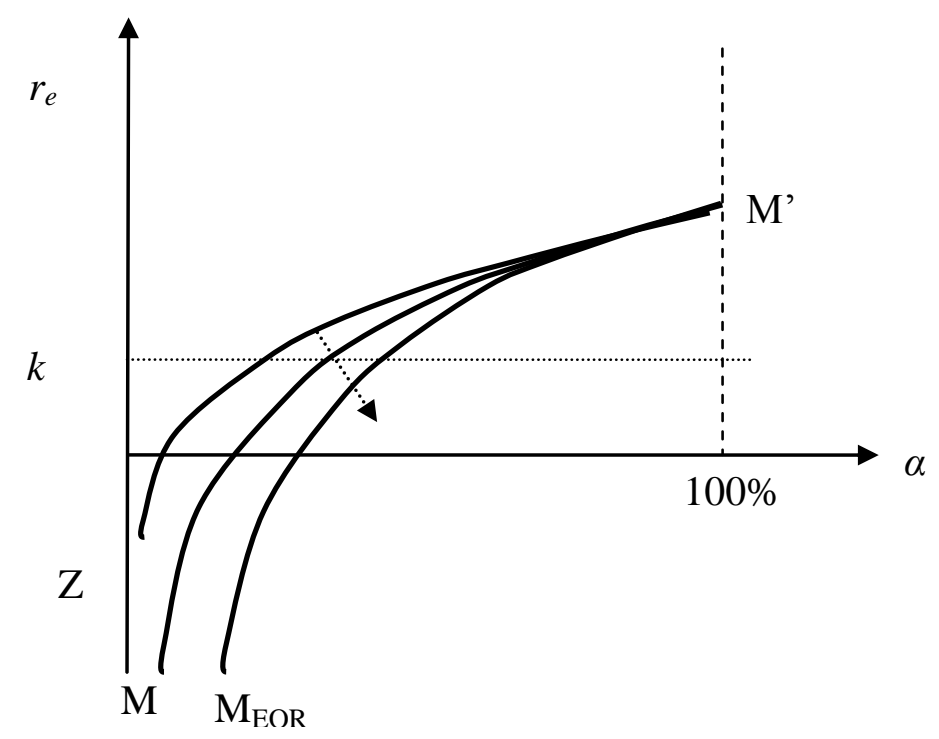

Figure 6: New controlling shareholder equilibrium choices with and without EOR system

The EOR system changes the location of the optimal choice curve of the controlling shareholder by moving it away from the situation ZM', corresponding to the absence of private benefits. The situation is more complex insofar as private benefits play a more important role in setting the equilibrium curve with EOR. The derivative or $r_{e}($.$) with regard to \gamma$ is more sensitive in such a situation. For a given value of new economic profitability, the controlling shareholder would own a larger stake of capital, which would lead him to expropriate less. In that sense, the EOR system leads to enhanced disciplinary pressure. At the limit, for low values of $\gamma$, the choices converge more quickly toward the no private benefits case.

\section{3) Joint equilibrium setting}

The final equilibrium between the two acting parties depends on the choice of $\alpha_{g}$ set by outside shareholders. For these outside shareholders, the equilibrium is a function of the net economic profitability of the firm after subtraction of private benefits. The final setting by the controlling shareholder will integrate the number of shares he will buy following the EOR procedure. 


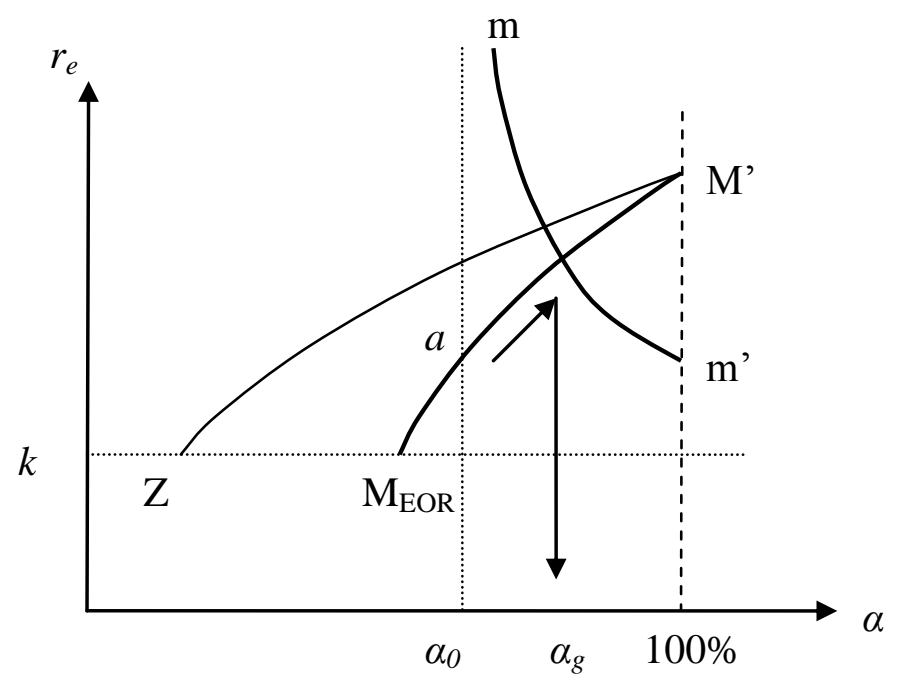

Figure 7: Equilibrium choice of controlling shareholder and outside investors

The acquirer who buys a control block $\alpha_{0}$ may think that it is enough for him to locate on his equilibrium curve $\mathrm{M}_{\mathrm{EOR}} \mathrm{M}^{\prime}$ at point $a$ (see Figure 7 ) and to issue the signal $\alpha$, which corresponds to a profitability $r_{e}$ optimal for him. Receiving that information on the block size, the optimal ownership of minor investors is located on the curve mm' at the same vertical level as that of point $a$. The implied $r_{e}$ is so weak that all outside investors will stand at point m', exercise their exit options, and bring their shares to the new controlling shareholder. The latter will get $\left(\alpha+\alpha_{g}\right)=100 \%$ and will be pushed away from his equilibrium curve $\mathrm{M}_{\mathrm{EOR}} \mathrm{M}$ '. The only common equilibrium contract is the point defined by the intersection of the two curves $\mathrm{M}_{\mathrm{EOR}} \mathrm{M}^{\prime}$ and $\mathrm{mm}$ '. Figure 7 mixes the equilibrium sets of the controlling shareholder (Figure 6) and of the minor investors (Figure 5). The intersection point means an announcement of higher future economic profitability, the selling of a fraction $\alpha_{g}$ of the capital through the EOR mechanisms and/or, on the minor investors' side, a lesser fear of appropriation.

The above analysis assumes an endogenous implicit value $t_{A}$ because the equilibrium curve mm' set for the outside shareholders refers in fact to the net economic return $\left(r_{e}-t_{A}\right)$. A complementary rationale for convergence is to condition the delivered information to attract outside investors toward the desired global participation stake $\alpha^{*}$, corresponding to an economic future profitability $r_{e}\left(\alpha^{*}\right)$ lower than $r_{e}\left(\alpha+\alpha_{g}\right)$. A bias of exaggeration or undervaluation of $r_{e}$ cannot be envisaged in this framework because the controlling shareholder delivers a signal through objective variables on the economic profitability of the firm and he 
does not manipulate information (see equation (5)). The private information on the true value of $r_{e}$ is exogenous and conditions the process. It is disseminated in the setting of the quantity equilibrium. In order to modify the shape and the location of the curve mm', other possibilities exist. The first way could be to modify the acquisition price $A$. This may be an eventuality in a tender offer where the problem of the acquirer is at the same time to gain control and to forecast the consequences of the mandatory bid rule. In that case, $\alpha_{g}$ is the percentage of shares bought above the controlling shareholder's initially targeted control stake. This eventuality is not opened up after a block trade. The price $A$ results from a negotiation between the previous and the new controlling blockholders. The second way is to publicly announce that the desired stake of capital is $\left(\alpha+\alpha_{g}\right)$. This integrates the demand function for the stocks of the outside investors. The third way is to reduce $t_{A}$, which is under the new shareholder's responsibility. This is signaled to outside investors through an increase in $\alpha$. The controlling shareholder may modify the slope parameter of the expropriation rate $\gamma$ and then, for a given value $\alpha_{0}$ of a control block bought in a block deal, set the implicit $t_{A}^{*}$ at a lower level. Reducing the appropriation rate shifts downward the equilibrium locus $\mathrm{mm}$ ' of outside shareholders and consequently moves the equilibrium point with $\mathrm{M}_{\mathrm{EOR}} \mathrm{M}^{\prime}$ to the left, which results in a lower value $\alpha_{g}$ for the shares brought through the mandatory bid procedure (see Figure 8).

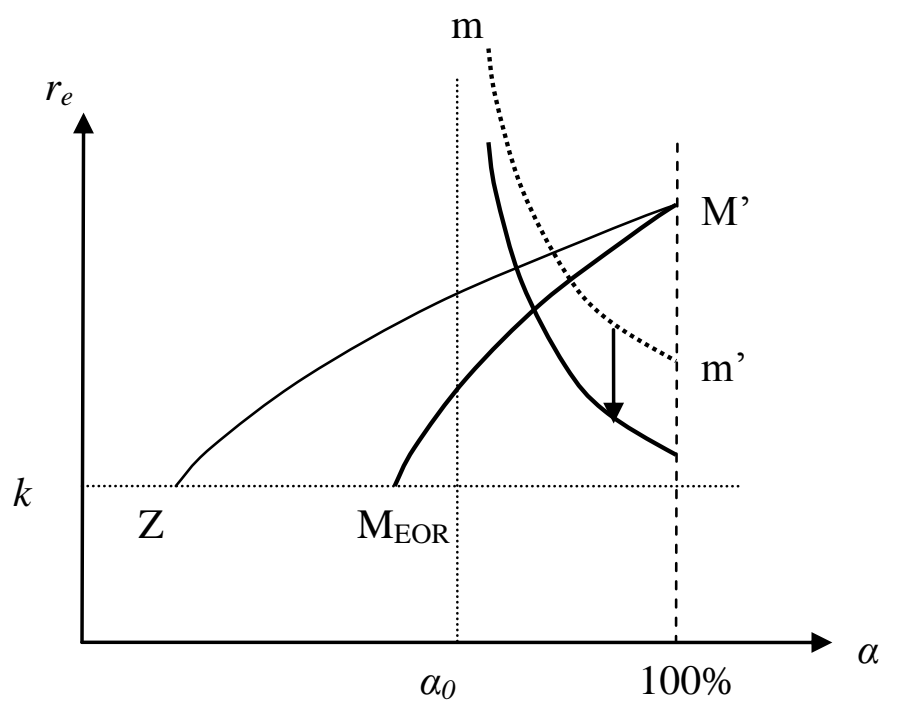

Figure 8: Equilibrium choices of controlling shareholder and outside investors with lower appropriation rate

The joint equilibrium framework recognizes that the two parties interact. That equilibrium mixes directly quantity and information. The price is constrained by legal rules and the takeover context. Only the quantities can adjust, and the total stake of capital after EOR of 
the controlling shareholder must be equal to the ownership percentage wished by minor investors. This Cournot equilibrium finds its own regulation with the future economic profitability that is announced by the new controller and what he intends to achieve. In a rational equilibrium schedule, this equilibrium defines an implicit contract between the new blockholder and the outside shareholders. They exchange quantities and information on future profits. Rational behavior pushes the acquirer to disclose the true economic value and to share this information with other investors. In an EOR system, the percentage of capital is an economically valuable signal and minor investors are not passive. In a concentrated blockholder ownership system, it also signals the existence of private benefits. Those are the adjustment variables in the hands of the controlling shareholder.

Consequently, the EOR modifies the behaviors in a situation of appropriation of private benefits. For a targeted ownership stake in capital, it puts pressure on the appropriation rate. The economic calculus of a rational new blockholder is made more complex. Through this ownership percentage, he is pushed to issue a signal on the true future economic profitability of the target firm $r_{e}$. The quality of information is better and the discipline stronger. The regulating mechanism is simple: in order to avoid the risk of owning a final stake of capital higher than the one aimed at, the controlling shareholder will lessen his private appropriation of benefits. The utility of the EOR rule is to introduce a complex and non-flat offer curve from the outside investors. This non-flat curve enriches their optimum behavior in partially tendering their shares to the offer and partially holding them to benefit from increase in the price in the posttrade market. It insures a joint equilibrium between both parties.

The mandatory bid rule underlines the nature of private benefits, which are uncertain and contingent on the new controlling shareholder. They cannot be considered as given and exogenous in a transfer of control, but rather as a regulation variable in the controlling-outside investors' agency problem. It is for this reason that we need to analyze separately the past private benefits paid back to the former controlling shareholder and the future private benefits. The normative solution to issue preferred shares to compensate controlling shareholders in a concentrated ownership system, as proposed by Hofstetter (2006), is not adapted in the sense that it sets once and forever the amount of accepted private benefits. The mandatory bid rule appears as a common and mandatory opportunity to "negotiate" an implicit contract between the new controlling shareholders and the outside investors and to question the accepted ex ante level of private benefits. It helps to make explicit what is implicit. 
The quality of information may also improve in the sense that the signal given to outside investors should be stronger. We highlight the fact that equal opportunity rules lower the prospects of private benefits. We also outline that in a controlling ownership system, the equal opportunity rule modifies the information delivered to outside investors: the same signal lead to lower forecasts of profitability. To balance this effect, we analyzed the possibility for the buyer to modify his choices. However, the acquirer may also issue directly private information about his willingness to expropriate less or disclose the true perspectives of future returns. In financial markets, rules may also force the buyer to disclose information. In addition, analysts may provide the market with information about the transactions. Outside investors are informed by other sources than the information delivered through the two channels used by the acquirer and identified in the model. The buyers may enter in a signaling game because otherwise they will not be at optimum and not maximize their profit.

\section{Conclusion}

The existence of the equal opportunity rule appears as far more important in a context of concentrated stock ownership and private benefits of control than in a framework of dispersed ownership. In a transfer of control, the possibility of a change in appropriation of the cash flow by the new controlling investor exists and is a source of risk for minor investors. The acquirer can use the bid acquisition price and his target ownership stake as signals to condition the takeover process.

This paper develops an analysis within a quasi-process of negotiation. The equal opportunity rule is not an explicit contract, but a conditioning regulation. It leads to an interaction between the new controlling shareholder and outside investors that characterizes an implicit contract. The terms have to be jointly settled regarding common variables: the number of shares brought to the exit opportunity option, and the appropriation rate of private benefits. The joint equilibrium framework recognizes that the two parties interact. A partial use of the exit option given to outside investors finds a rational explanation in our model. The characteristics of the joint equilibrium mixes directly quantity and information. In a no EOR the acquirer is not ex ante insured to get his optimum stake of the target and is in a risky position of staying with $\alpha_{0}$ (for instance in a private block acquisition) or to buy $100 \%$ of the shares in a public takeover.. 
In an unconditional takeover with EOR, only the quantities can adjust and the total stake of capital of the controlling shareholder must be equal to the ownership percentage wished for by minor investors. The EOR rule introduces a complex and non-flat offer curve from the outside investors. This explains why they split their holding between partial tendering of their shares to the exit offer and partial holding. In an EOR system, the percentage of capital brought to the offer is an economically valuable signal and minor investors are not passive. It also signals the existence of private benefits in a concentrated blockholding system. Ex ante private benefits and share of capital held are the adjustment variables in the hands of the controlling shareholder. As a consequence, the EOR modifies the behaviors in a situation of appropriation of private benefits. For a targeted ownership stake in capital, this puts pressure on the appropriation rate. The regulating mechanism is simple: in order to avoid the risk of owning a final stake of capital higher than the one aimed at, the controlling shareholder will lessen his private appropriation of benefits. Outside investors participate in the setting of the equilibrium. They may profit from a better discipline on the forecasted private appropriation. However, the signals at the disposal of the controlling investor are less effective and the quality of the information delivered to the market is lower in comparison with a situation without an equal opportunity rule. By making things more complex, regulation may lower the quality of a given signal and make the transactions or the negotiation processes more difficult. The equal opportunity rule or mandatory bid mechanisms illustrate this feature. They put a pressure to buyer's choices to balance lower quality signals.

Regulation thus initiates a constrained contractual process, which in itself may create economic value. The progress toward an agreement is not a "take it or leave it" situation. Both parties will, to some extent, exchange possibly biased information. Information asymmetry is part of the deal and a disclosure of private information has the same effect as a price discount. The contractual process in itself is important, so allowing contractual freedom or developing a private negotiation phase in the takeover process, has value. In a context of concentrated ownership and private benefit a new implicit contracts between controlling and outside investors arises when transfers of control occur. The existence of a process of negotiation is more frequent than typically seen (Boone and Mulherin, 2007). Our paper brings some explanation argument in a context of expropriation of private benefits. Within an EOR system, the weaker party is not an automatic loser. The exit option given to outside shareholders is a tool to curb possible future private expropriation. The contractual process creates value when it 
leads to better ex ante information, at least for one party. The equal opportunity rule as an external regulation is an example of an implicit bilateral contract, which imposes an overall disciplinary pressure.

The legal environment appears important because it modifies and improves the equilibrium contract locus and the value of the firm in comparison with the absence of a price guarantee mechanism. In a world without mandatory EOR, a buyer is free to create an EOR by announcing he wants to purchase all shares at the bid price. Buyer usually seems to reject this option, which implied that EOR is not privately optimal. Then the EOR makes the buyers worse off. However, we show that the rule makes the investors well off by increasing the information they would otherwise have and by reducing private benefit expropriation. We have not analyzed if the EOR effect is only distributional. From a social public choice perspective, the welfare property of EOR has still to be analyzed.

\section{References}

Albuquerque R., Schroth E., 2010, Quantifying private benefits of control from a structural model of block trades, Journal of Financial Economics, 96, 33-55

At C., Chappe N., Morand P.H., 2004 Sentencing private benefits in takeover contest, International Review of Law and economics, 24, 409-424

Atanasov V., Boone A. Haushalter D., 2010, Is there shareholder expropriation in the United States? An analysis of publicly traded subsidiaries, Journal of Financial and Quantitative Analysis, 45, 1-26

Bagnoli M., Lipman B. 1988, Successful takeovers without exclusion, Review of Financial Studies, 1, 89-110.

Barclay, M., Holderness C., 1989, Private benefits of control of public corporations, Journal of Financial Economics, 25, 371-395.

Barclay, M., Holderness C., 1991, Negotiated block trades and corporate control, Journal of Finance, 46, 861-878.

Bebchuk L. A., 1989, Takeover bids below the limited value of minority shares, Journal of Financial and Quantitative Analysis, 24, 171-184.

Bebchuk, L. A., 1994, Efficient and inefficient sales of corporate control, Quarterly Journal of Economics, 109, 957-993. 
Bebchuk, L. A., 1999, A rent protection theory of corporate ownership and control, Harvard Law and Economic, discussion paper $n^{\circ} 260$.

Berglöf, E., Burkart M., 2003, European takeover regulation, Economic Policy, 36, 171213.

Bergstrom C., Högfeldt P., Molin J., 1997, The optimality of the mandatory bid rule, Journal of Law, Economics and Organization, 132, 433-451

Bolton, P., von Thadden E., 1998, Blocks, liquidity and corporate control, Journal of Finance, $53 n^{\circ} 1,1-25$.

Boone A., Mulherin J.H., 2007 How are firms sold? Journal of Finance, 622, 847-875

Bris A., Cabolis C., 2008, The value of investor protection: Firm evidence from crossborder mergers, Review of Financial Studies, 212, 605-648

Burkart, M., Gromb D., Panunzi F., 1998, Why higher takeover premia protect minority shareholders, Journal of Political Economy, 106, 172-204.

Burkart, M., Gromb D., Panunzi F., 2000, Agency conflicts in public and negotiated transfers of corporate control, Journal of Finance, 55, 647-677.

Burkart, M., Gromb D., Mueller H., Panunzi F., 2012, Legal investor protection and takeovers, working paper, Paris Corporate Finance Conference, may

Burkart, M., Panunzi F., 2004, Mandatory bids, squeeze-out, sell-out and the dynamic of the tender offer process, in G. Ferrarini et al. (eds), Modern company and takeover law in Europe, p. 737-765, Oxford University Press, Oxford.

Carvalhal da Silva A., Subrahmanvam A., 2007 Dual-class premium, corporate governance, and the mandatory bid rule: Evidence from the Brazilian stock market, Journal of Corporate Finance, 131, 1-24

Davies P., Hopt K., 2004, Control transactions in Kraakman R. et al. (eds), The Anatomy of Corporate Law, A comparative and functional approach, p.157-191, Oxford University Press, Oxford.

Doidge C., Karolyi G.A., Stulz R., 2004, Why are foreign firms listed in the U.S. worth more?, Journal of Financial Economics, 712, 205-238

Dyck A., Zingales L., 2004, Private benefits of control: An international comparison, Journal of Finance, 59, 537-600

Enriques L. 2012 The mandatory bid rule in the takeover directive: Harmonization without foundation?, European Company and Financial Law Review, 14, 440-457

Enriques L., Gilson R., Pacces A., 2013, The Case for an unbiased takeover law with an application to the European Union, ECGI - Law Working Paper No. 212, Columbia Law and 
Economics Working Paper No. 450, Stanford Law and Economics Olin Working Paper No. 444. Available at SSRN: http://ssrn.com/abstract=2258926

Goergen M., Martynova M., Renneboog L., 2005, Corporate governance convergence: Evidence from takeover regulation reforms in Europe, Oxford Review of Economic Policy, 21 2, 243-268.

Grant J., Kirchmaier T., Kirshner J., 2009, Financial tunneling and the mandatory bid rule. European Business Organization Law Review, 10, 233-253.

Grossman S. J., Hart O.D., 1980, Takeover bids, the free-rider problem and the theory of the corporation, Bell Journal of Economics, 11, 42-64.

Hirshleifer, D., Titman S. 1988, Share tendering strategies and the success of hostile takeover bids, Journal of Political Economy, 98 n², 295-324.

Hofstetter, K. 2006, One size does not fit all: A corporate governance for controlled companies, North Carolina Journal of International Law and Commercial Regulation, 31(3), 597-663.

Holderness C. 2009, The Myth of Diffuse Ownership in the United States, Review of Financial Studies, 22(4), 1377-1408.

Holmen M., Novorozhkin E., 2007, Tender offers versus block trade: Empirical evidence, working paper, Milano EFMA Meeting, May 2007.

Kim E.H., Lu Y., 2013, Corporate governance reforms around the world and crossborder acquisitions, Journal of Corporate Finance, 22, 236-253

Köke J., Renneboog L., 2005, Do corporate control and product market competition lead to stronger productivity growth? Evidence from market-oriented and blockholder-based governance regimes, Journal of Law and Economics, 48, 475-516.

La Bruslerie, H. de, Deffains-Crapsky C., 2004, Takeover bids, offer price and investor protection, Review of Financial Economics, 14(2), 103-126.

La Porta, R., Lopez-de-Silanes F., Shleifer A., Vishny R. 1998 Law and finance, Journal of Political Economy, 106(6), 1113-1155.

La Porta, R., Lopez-de-Silanes F., Shleifer A., 1999, Corporate ownership around the world, Journal of Finance 54, 471-517.

Leland, H, Pyle D. 1977, Informational asymmetries, financial structure and financial intermediation, Journal of Finance, 32(2), 371-387.

McCahery J., Vermeulen T., 2010 Does the Takeover Bids Directive Need Revision? TILEC Discussion Paper No. 2010-006; Tilburg Law School Research Paper No. 005/2010. Available at SSRN: http://ssrn.com/abstract=1547861 
Pagano M., Volpin P., 2005, The political economy of corporate governance, American Economic Review, 954, 1005-1030

Papadopoulos T., 2007, The mandatory provisions of the EU takeover bid directive and their deficiencies, Law and Financial Markets Review, 1(6), 525-533

Papadopoulos T., 2013 Acquisition of corporate control and clear criteria in the adjustment of the mandatory bid price, Law and Financial Markets Review, 7(2), 97-106

Rossi S., Volpin P. 2004 Cross-country determinants of mergers and acquisitions, Journal of Financial Economics, 74(2), 277-304

Schatt A., Roy T., 2004, Etude des déterminants de la prime d'acquisition d'un bloc de contrôle: Le cas français, working paper, LEGO, University of Bourgogne.

Schuster E.P., 2010, Efficiency in private control sales - The case for mandatory bids, working paper 08/2010, London School of Economics, available at SSRN: http://ssrn.com/abstract=1610259

Schuster E.P., 2013, The mandatory bid rule: Efficient, after all? The Modern Law Review, 76(3), 529-563

Sepe S., 2010 Private sale of corporate control: Why the European mandatory bid rule is inefficient, Arizona Legal Studies Discussion Paper No. 10-29. Available at SSRN: http://ssrn.com/abstract=1086321

Shleifer A., Vishny R., 1986, Large shareholdings and corporate control, Journal of Political Economy, 94, 461-488. 


\section{Annex}

To solve the differential equation (A1), we call $g(\alpha)$ the left hand side:

$$
g(\alpha)=\frac{d r_{e}(.)}{d \alpha}+\frac{r_{e}(.)}{\alpha}=\frac{\left(2 \gamma+\frac{A k}{V_{e}}\right)}{\alpha}-2 \cdot \gamma+\frac{1}{\mu}\left(\frac{V_{e}}{k}\right) \sigma_{x}^{2}
$$

The solution has the form:

$$
r_{e}(\alpha)=K(\alpha) e^{-\ln (\alpha)}=\frac{1}{\alpha} K(\alpha)
$$

Deriving (A2) with regard to $\alpha$ gives:

$$
\frac{d r_{e}(.)}{d \alpha}+\frac{r_{e}(.)}{\alpha}=\frac{1}{\alpha} K^{\prime}(\alpha)=g(\alpha)
$$

Using (A1):

$$
K^{\prime}(\alpha)=\left(2 \gamma+\frac{A \cdot k}{V_{e}}\right)+\left[\frac{1}{\mu}\left(\frac{V_{e}}{k}\right) \sigma_{x}^{2}-2 \gamma\right] \alpha
$$

Integrating (A3):

$$
K(\alpha)=\left(2 \gamma+\frac{A . k}{V_{e}}\right) \alpha+\left[\frac{1}{\mu}\left(\frac{V_{e}}{k}\right) \sigma_{x}^{2}-2 \gamma\right] \frac{\alpha^{2}}{2}+c
$$

Where $c$ is an integration constant and using (A2), we finally get:

$$
r_{e}(\alpha)=\left(2 \gamma+\frac{A k}{V_{e}}\right)+\left[\frac{1}{\mu}\left(\frac{V_{e}}{k}\right) \sigma_{x}^{2}-2 \gamma\right] \frac{\alpha}{2}+\frac{c}{\alpha}
$$

